\title{
Speciation among sympatric lineages in the genus Palythoa (Cnidaria: Anthozoa: Zoantharia) revealed by morphological comparison, phylogenetic analyses and investigation of spawning period
}

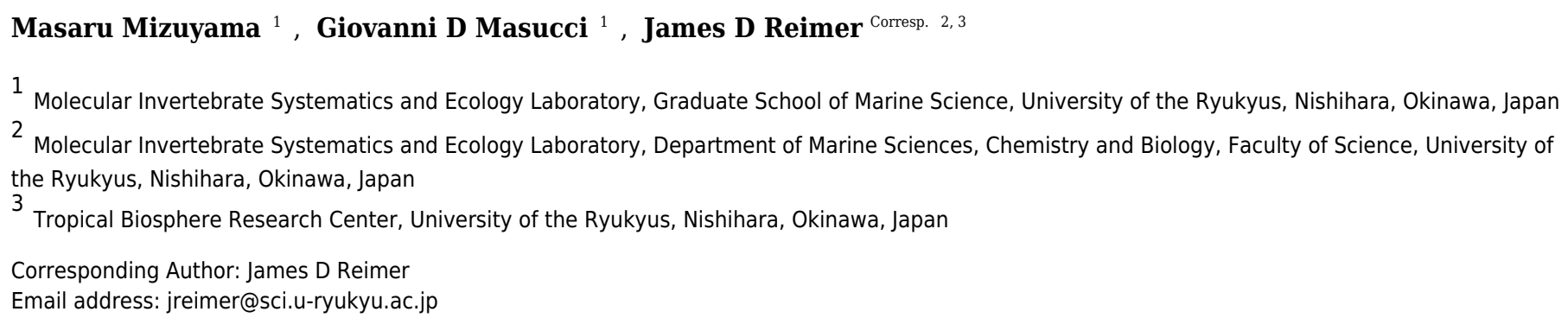

Zoantharians are sessile marine invertebrates and colonial organisms possessing sexual and asexual reproductive ability. The zooxanthellate zoantharian genus Palythoa is widely distributed in coral reef ecosystems. In the Ryukyu Archipelago, Japan, sympatric Palythoa tuberculosa and $P$. mutuki are the dominant species of this genus in the intertidal zone. Previous phylogenetic analyses have shown that these two species are closely related, and additionally revealed a putative sympatric hybrid species (designated as Palythoa sp. yoron). In this study, we attempted to delineate Palythoa species boundaries and to clarify the relationships among these three groups plus another additional putative sympatric species ( $P$. aff. mutuki) by multiple independent criteria. The morphology of these four lineages was clearly different; for example the number of tentacles was significantly different for each species group in all pairwise comparisons. From observations of gonadal development conducted in 2010 and 2011, P. sp. yoron and $P$. aff. mutuki appear to be reproductively isolated from $P$. tuberculosa. In the phylogenetic tree resulting from maximum likelihood analyses of the ITS-rDNA sequence alignment, $P$. tuberculosa and $P$. sp. yoron formed a very well supported monophyletic clade $(\mathrm{NJ}=100 \%, M L=95 \%$, Bayes $=0.99$ ). This study demonstrates that despite clear morphological and/or reproductive differences, $P$. tuberculosa and $P$. sp. yoron are phylogenetically entangled and closely related to each other, as are $P$. mutuki and $P$. aff. mutuki. Additionally, no single molecular marker was able to divide these four lineages into monophyletic clades by themselves, and a marker that has enough resolution to solve this molecular phylogenetic species complex is required. In summary, the morphological and reproductive results suggest these lineages are four separate species, and that incomplete genetic lineage sorting may prevent the accurate phylogenetic detection of distinct species with the DNA 
markers utilized in this study, demonstrating the value of morphological and reproductive data when examining closely related lineages. 
5 Authors: Masaru Mizuyama ${ }^{\mathrm{a}^{*}}$, Giovanni Diego Masuccia ${ }^{\mathrm{a}}$, James Davis Reimer ${ }^{\mathrm{b}, \mathrm{c}}$

7 Affiliation

8 aMolecular Invertebrate Systematics and Ecology Laboratory, Graduate School of Marine

9 Science, University of the Ryukyus, Nishihara, Okinawa, Japan; e-mail: mizuyama58@live.jp,

10 giovannimasucci@me.com

11 bMolecular Invertebrate Systematics and Ecology Laboratory, Department of Marine Sciences, 12 Chemistry, and Biology, Faculty of Science, University of the Ryukyus, Nishihara, Okinawa, 13 Japan; e-mail: jreimer@sci.u-ryukyu.ac.jp

$14{ }^{\mathrm{c} T}$ Tropical Biosphere Research Center, University of the Ryukyus, Nishihara, Okinawa, Japan $15 *$ corresponding author; e-mail: jreimer@sci.u-ryukyu.ac.jp 16 


\section{Abstract}

18 Zoantharians are sessile marine invertebrates and colonial organisms possessing sexual

19 and asexual reproductive ability. The zooxanthellate zoantharian genus Palythoa is widely

20 distributed in coral reef ecosystems. In the Ryukyu Archipelago, Japan, sympatric Palythoa

21 tuberculosa and P. mutuki are the dominant species of this genus in the intertidal zone. Previous

22 phylogenetic analyses have shown that these two species are closely related, and additionally

23 revealed a putative sympatric hybrid species (designated as Palythoa sp. yoron). In this study,

24 we attempted to delineate Palythoa species boundaries and to clarify the relationships among

25 these three groups plus another additional putative sympatric species ( $P$. aff. mutuki) by multiple

26 independent criteria. The morphology of these four lineages was clearly different; for example

27 the number of tentacles was significantly different for each species group in all pairwise

28 comparisons. From observations of gonadal development conducted in 2010 and 2011, P. sp.

29 yoron and $P$. aff. mutuki appear to be reproductively isolated from $P$. tuberculosa. In the

30 phylogenetic tree resulting from maximum likelihood analyses of the ITS-rDNA sequence

31 alignment, $P$. tuberculosa and $P$. sp. yoron formed a very well supported monophyletic clade

$32(\mathrm{NJ}=100 \%, \mathrm{ML}=95 \%$, Bayes $=0.99)$. This study demonstrates that despite clear morphological

33 and/or reproductive differences, $P$. tuberculosa and $P$. sp. yoron are phylogenetically entangled

34 and closely related to each other, as are $P$. mutuki and $P$. aff. mutuki. Additionally, no single

35 molecular marker was able to divide these four lineages into monophyletic clades by themselves,

36 and a marker that has enough resolution to solve this molecular phylogenetic species complex is

37 required. In summary, the morphological and reproductive results suggest these lineages are four

38 separate species, and that incomplete genetic lineage sorting may prevent the accurate

39 phylogenetic detection of distinct species with the DNA markers utilized in this study, 
40 demonstrating the value of morphological and reproductive data when examining closely related

41 lineages.

42

43

\section{Introduction}

Zoantharians are sessile marine invertebrates and colonial organisms possessing sexual and asexual reproductive ability (Ryland 1997). Zoantharians belong to subclass Hexacorallia (Cnidaria, Anthozoa) and they have the significant feature of embedding small particles (sand, detritus) into their body column. Zooxanthellate zoantharian species are found worldwide in tropical and subtropical shallow water areas (Trench 1974, Reimer et al. 2006).

Traditionally, zoantharian classification has been based on morphological characters such as the relative degree of coenenchyme development, number of tentacles per polyp, oral disk diameter, and position and features of the sphincter muscle (Ryland and Lancaster 2003). However, sand encrustation (Reimer et al. 2010) and large intraspecific variation have often made histological classification difficult (Muirhead and Ryland 1985, Mueller and Haywick 1995, Reimer et al. 2010). Phylogenetic work using mitochondrial 16S ribosomal DNA and cytochrome oxidase subunit I (mtCOI) and the nuclear internal transcribed spacer region of ribosomal DNA (ITS-rDNA) as molecular markers have begun to reveal evolutionary relationships in this group (e.g. Reimer et al. 2004, Sinniger et al. 2005, Reimer et al. 2007b).

The zooxanthellate zoantharian genus Palythoa Lamouroux, 1816 is widely distributed in coral reef ecosystems as a common group of organisms. In the Ryukyu Archipelago of southern Japan (Fig. 1), Palythoa tuberculosa (Esper, 1805) and P. mutuki Haddon \& Shackleton, 1891 are the dominant species of this genus in the intertidal zone (Irei et al. 2011). Reimer et al. (2007a) showed that these two species are closely related with phylogenetic analyses based on 
63 ITS-rDNA and mtCOI. Furthermore, they revealed a putative hybrid species (designated as

64 Palythoa sp. yoron), which was presumed to have originated via interspecies hybridization

65 between $P$. tuberculosa and P. mutuki, based on shared additive patterns of nucleotide

66 polymorphisms of ITS-rDNA sequences, and indicated a potential reticulate evolutionary history

67 in these three species groups. A subsequent investigation conducted by Shiroma and Reimer

68 (2010) revealed that $P$. sp. yoron was sympatric in the intertidal zone with these two other

69 species in Okinawa, but also was present in a different microenvironment than $P$. tuberculosa

70 and $P$. mutuki. As well, $P$. sp. yoron is intermediate in morphological form between $P$.

71 tuberculosa and P. mutuki. (Fig. 2, Table 1), with all three species readily distinguishable from

72 one another (Shiroma and Reimer 2010).

In this study, we attempted to determine the delimitation of Palythoa species

74 boundaries and to clarify the relationships among species groups using multiple independent

75 criteria. We first made primary hypotheses of species delimitation based on morphology and

76 habitat preference. We then re-examined these hypotheses via genetic data and investigated

77 ovary development through time as a proxy to clarify the timing of spawning and the possibility

78 of cross-hybridization among putative species.

79 Materials and Methods

80 Specimen collection

81 Specimens of Palythoa species were collected in the intertidal zone from several sites in

82 the Ryukyu Archipelago, including Okinawa-jima Island, Yoron-to Island, Okinoerabu-jima

83 Island, and Tokunoshima Island (Fig. 1, Table 2) between March 2010 to October 2012. All

84 specimens were stored in $99.5 \%$ ethanol for DNA analyses or $5 \%$ formalin-SW solution for

85 morphological and anatomical analyses. 
87 (Pax 1910), supplemented with a key to field identification (Reimer 2010), and ecological and 88 morphological aspects of $P$. sp. yoron (Shiroma and Reimer 2010). Characters employed for 89 identification of Palythoa species were environment (habitat), coenenchyme development, polyp 90 structure, number of polyps per colony, and numbers of tentacles per polyp. All specimens were 91 identified preliminarily as Palythoa tuberculosa (Fig. 2 A), P. mutuki (Fig. 2 B) and P. sp. yoron 92 (Fig. 2 C). During collection, it was noticed that certain specimens had a similar external 93 appearance with $P$. mutuki but with less well developed marginal ridges and larger polyp sizes. 94 Such specimens were found sympatrically with other specimens, and these were designated as $P$. 95 aff. mutuki (Fig. 2 D). In addition, spawning timing investigations for all species groups were 96 carried out between June 2010 to December 2010, and from June 2011 to February 2012 at 97 Kaminomine, Tokunoshima, Kagoshima $\left(27^{\circ} 46^{\prime} 09^{\prime \prime} \mathrm{N}, 129^{\circ} 02^{\prime} 16^{\prime \prime}\right.$ E) by monthly sampling. 98 In particular, for collecting $P$. tuberculosa, investigation was conducted in a wide area from 99 lagoon tide pools to the outer reef in 2010. However, in 2011-2012 investigations were 100 conducted only in tide pools due to rough sea conditions. At least five different colonies of 101 approximately ten polyps for each species were collected in whole or partially.

102 Morphological analyses

103 External anatomy

104 Fixed specimens were cut horizontally at the oral disk height by surgical knife and 105 tweezers under stereomicroscope (S8APO, Leica, Tokyo) and the number of tentacles, which is 106 one of the characters for Palythoa species (e.g. Ryland and Lancaster 2003), were counted

107 (Table 3). To eliminate pseudo-replication in comparison among species, a single polyp was 108 chosen with the table of random number from each colony. The mean numbers of tentacles per 
109 polyp for each species pair were compared using Mann-Whitney $U$ test with Bonferroni

110 correction.

\section{Cnidae}

112 Cnidae analyses were conducted using undischarged nematocysts from the tentacles,

113 column, pharynx, and mesenteriel filaments of polyps ( $\mathrm{n}=3 /$ species group) under a Nikon

114 Eclipse80i stereomicroscope (Nikon, Tokyo). Cnidae sizes were measured using ImageJ v1.45s

115 (Rasband 2012). Cnidae classification followed England (1991) and Ryland and Lancaster

116 (2004; see also Table 4).

117 Spawning period investigation

118 Ovary development of all preserved colonies was observed via cross sections made by

119 cutting polyps vertically through the mouth located at the center of oral disk under a

120 stereomicroscope. During anthozoans' oogenesis, oocytes form a single-layered germinal

121 ribbon down the mesoglea of the central third of the septa. Subsequently, the germinal ribbon

122 develops a sequence of swollen nodes where the septum folds locally in an S and the layers fuse

123 (Ryland 1997, Ryland 2000). When we observed a germinal ribbon in a polyp, we counted the

124 polyp as "possessing developing ovaries", and the number of polyps possessing developing

125 ovaries were totaled. To evaluate the spawning period of each species, the ratio of the number of

126 polyps possessing developing and/or developed ovaries to the total number of polyps examined

127 was calculated over time. When the calculated proportion of developed/developing ovaries

128 dropped dramatically, we designated this as the start of the estimated spawning period. The end

129 of the estimated spawning period was defined as the point where the number of 130 developed/developing ovaries reached $0 \%$. 
131 Molecular analyses

132 DNA extraction, PCR amplification and direct sequencing

133 DNA from each specimen was extracted using a DNeasy Blood and Tissue Kit

134 (QIAGEN, Tokyo, Japan) according to the manufacturer's instructions. A small amount of tissue

135 from each specimen was removed using a surgical knife sterilized by open flame. Extracted

136 DNA was subsequently stored at $-20^{\circ} \mathrm{C}$, and then we amplified target sequences via polymerase

137 chain reaction (PCR).

138 Three molecular markers that have previously been used for differentiation of Palythoa

139 were chosen; 1) the mitochondrial 16S of ribosomal DNA (mt 16S-rDNA), 2) the mitochondrial

140 cytochrome c oxidase subunit I (mtCOI), and 3) the internal transcribed spacer region of nuclear

141 ribosomal DNA (ITS-rDNA) (Reimer et al. 2004, Sinniger et al. 2005, Reimer et al. 2007a, etc.).

142 Furthermore, a nuclear housekeeping gene, 4) asparagine-linked glycosylation 11 protein

143 (ALG11) region, was also examined for the first time in zoantharians. This marker has been

144 found to be more informative than mtCOI in examining sponge relationships and succeeded in

145 solving previously debated nodes, and has also been considered to be useful for resolving

146 cnidarian relationships (Belinky et al. 2012).

147 Thermal cycler programs were set to the following conditions: (1) mt 16S-rDNA; an

148 initial denaturing step at $94^{\circ} \mathrm{C}$ for 2 minutes, followed by 40 cycles of 30 seconds' $94^{\circ} \mathrm{C}, 1$

149 minute annealing at $52^{\circ} \mathrm{C}$ and 2 minutes' extension at $72^{\circ} \mathrm{C}$, followed by 5 minute final

150 elongation at $72^{\circ} \mathrm{C}$ with Zoantharia-specific primer set 16Santla (5'-GCC ATG AGT ATA GAC

151 GCA CA-3') and 16SbmoH (5'-CGA ACA GCC AAC CCT TGG-3') (Sinniger et al., 2005); (2)

$152 \mathrm{mtCOI} ; 1 \mathrm{~min}$ at $95^{\circ} \mathrm{C}$, then 35 cycles: $1 \mathrm{~min}$ at $95^{\circ} \mathrm{C}, 1 \mathrm{~min}$ at $40^{\circ} \mathrm{C}$ and $90 \mathrm{sec}$ at $72^{\circ} \mathrm{C}$,

153 followed by $7 \mathrm{~min}$ at $72^{\circ} \mathrm{C}$ with the universal primers $\mathrm{HCO} 2198$ (5'-TAA ACT TCA GGG TGA 
154 CCA AAA AAT CA-3') and LCO1490 (5'-TAA ACT TCA GGG TGA CCA AAA AAT CA-3')

155 (Folmer et al. 1994); and (3) ITS-rDNA; 1 min at $95^{\circ} \mathrm{C}$, then 35 cycles of 1 min at $94^{\circ} \mathrm{C}, 1 \mathrm{~min}$ 156 at $50^{\circ} \mathrm{C}$, and $2 \mathrm{~min}$ at $72^{\circ} \mathrm{C}$, followed by $10 \mathrm{~min}$ at $72^{\circ} \mathrm{C}$ with Zoantharia-specific primers Zoan-

157 f (5'-CTT GAT CAT TTA GAG GGA GT-3') and Zoan-r (5'-CGG AGA TTT CAA 158 ATT TGA GCT-3’) (Reimer et al. 2007a).

159 Amplification for the remaining coding region (ALG11) was performed by touch-down 160 PCR and nested PCR because of low numbers of copies in the whole genome as this is a single161 copy gene. For ALG11, although we basically followed the original protocols (Sperling et al. 162 2007, Belinky et al. 2012), some modifications were required to fit the thermal cycler we used, 163 and the conditions were as follows: (4) ALG11 first touchdown, 2 min at $95^{\circ} \mathrm{C}$, then 13 cycles of $1641 \mathrm{~min}$ at $95{ }^{\circ} \mathrm{C}, 1 \mathrm{~min}$ at $52-40^{\circ} \mathrm{C}$ (dropping one degree for each cycle), $1.5 \mathrm{~min}$ at $72^{\circ} \mathrm{C}$; 165 followed by 20 cycles of $1 \mathrm{~min}$ at $95^{\circ} \mathrm{C}, 1 \mathrm{~min}$ at $52^{\circ} \mathrm{C}, 1.5 \mathrm{~min}$ at $72^{\circ} \mathrm{C}$; lastly $5 \min$ at $72^{\circ} \mathrm{C}$ 166 with primers ALG11-D1 (5'-TTY CAY CCN TAY TGY AAY GCN GGN GG-3') and ALG11167 R1 (5'-ATN CCR AAR TGY TCR TTC CAC AT-3'), and (5) MAT-f (5'-GGN GAR GGN 168 CAY CCN GAY AA-3'). In the second touchdown procedure an amplicon of the first 169 touchdown was utilized as the template, followed by $2 \mathrm{~min}$ at $95^{\circ} \mathrm{C}$, then 35 cycles of $1 \mathrm{~min}$ at $17095^{\circ} \mathrm{C}, 1 \mathrm{~min}$ at $52^{\circ} \mathrm{C}$, and $1.5 \mathrm{~min}$ at $72^{\circ} \mathrm{C}$. In the end, nested PCR was performed with 2 min at $17195^{\circ} \mathrm{C}$, and then 35 cycles of $1 \mathrm{~min}$ at $95^{\circ} \mathrm{C}, 1 \mathrm{~min}$ at $52^{\circ} \mathrm{C}$, and $1.5 \mathrm{~min}$ at $72^{\circ} \mathrm{C}$ with primers 172 ALG11-D2 (5'-TGY AAY GCN GGN GGN GGN GGN GA-3') and ALG11-R2 (5'-CCR AAR 173 TGY TCR TTC CAC ATN GTR TG-3').

174 Amplicons were outsourced for sequencing to a private sequencing company (Fasmac 175 Co., Ltd., Kanagawa, Japan) on an Applied Biosystems 3730xl DNA sequencer, using BigDye 
176 Terminator V3.1 and the same primer sets as for PCR as described above. Sequence data were

177 edited using BioEdit v.7.2.0 (Hall, 1999).

178 Sequence alignment

179 The total number of novel sequences obtained from specimens in this study were (1) $\mathrm{mt}$

180 16S-rDNA; 38; (2) mtCOI; 20; (3) ITS-rDNA; 35 and (4) ALG11; 65, respectively. Obtained

181 sequences were aligned by BioEdit v7.2.0 (Hall 1999) with other sequences deposited in

182 GenBank (Table 5).

183 As numerous indels (inserts and deletions) were confirmed in ITS-rDNA sequences,

184 alignment was performed using ClustalW (Thompson et al. 1994) with gap penalties of 10 for

185 open and 1 for extended, followed by manual fixing for obviously misaligned areas such as gap

186 position. Sequences of the 5.8S rDNA region located between internal transcribed spacer 1

187 (ITS1) and internal transcribed spacer 2 (ITS2) were removed from analyses because the

188 substitution rate is apparently lower than ITS1 and ITS2, and an admixture of different

189 substitution rates could lead to a misleading choice of the appropriate substitution model.

190 Additionally, in order to not overestimate for genetic distance in following phylogenetic

191 analyses, sites were removed if they had a percentage of gaps and/or ambiguous sites higher

192 than 95\% (partial-deletion option).

193 Fifty-six out of sixty-five specimens had one or more degenerate codes in sequences of

194 the ALG11 region. All degenerate codes were divided into two standard bases using PHASE

195 v2.1.1, which implements a Bayesian statistical method for reconstructing haplotypes from

196 population genotype data (Stephens et al. 2001, Stephens and Scheet 2005). Furthermore, first

197 and second codon positions were removed from the dataset by checking amino acid sequences

198 after translation. 
Thus, each dataset was modified as needed, with additional previously reported 200 sequences added from GenBank, and we generated four alignments; (1) mtCOI; 451 bp of 47

201 sequences; (2) mt 16S-rDNA; 697 bp of 54 sequences; (3) ITS-rDNA; 317 bp of 60 sequences 202 and (4) ALG11; 578 bp of 121 sequences. These were used for subsequent phylogenetic 203 analyses.

204 Substitution model selection

Substitution models for each gene were estimated by jModelTest v2.1.3 (Posada et al. 206 2012) through the following steps. Initially, likelihood calculations were carried out for all

207 substitution models with configurations of 7 substitution schemes, equal or unequal base 208 frequencies $(+\mathrm{F})$, rate variation among sites with a number of rate categories $(+\mathrm{G}$, nCat 5$)$ and 209 base tree topology (ML optimized). Subsequently, the most appropriate model for each marker 210 was selected under (i) the corrected Akaike information criterion (AICc) for Maximum211 Likelihood and neighbor-joining phylogenetic estimation, or (ii) Bayesian information criterion 212 (BIC) for Bayes estimation. Thus, the (i)TrN/(ii)TrNef for mt 16S-rDNA, (i)F81/(ii)JC for

213 mtCOI, (i,ii)K80+ $\Gamma$ for ITS-rDNA, and (i)K80 $+\Gamma /(i i) T P M 1 u f+\Gamma$ models for ALG11 were 214 employed, respectively.

\section{Gene tree estimations}

216 For four distinct datasets (mt 16S-rDNA, mtCOI, ITS-rDNA, ALG11), phylogenetic 217 analyses were applied independently with the optimal substitution model under AICc estimated 218 by jModelTest. Maximum-Likelihood (ML) analyses were performed using PhyML (Guindon 219 and Gascuel 2003) and neighbor-joining (NJ) methods were performed using MEGA5.2.2 220 (Tamura et al. 2011). All other parameters besides substitution model and the discrete gamma 
221 distribution were implemented with the default value. Bootstrap analyses (Felsenstein 1985) of

2221000 replicates were tested to evaluate the support of every branch.

223 Bayesian inference for gene trees was performed using BEAST v.1.8.0 (Heled and

224 Drummond 2010) with the optimal substitution model under BIC. All parameters were used as

225 default values except for the molecular clock, in which the rate was changed to the log-normal

226 relaxed model, while only the substitution model for ALG11 was modified to TPM1uf after

227 generating the initial setting file. Four Markov chain Monte Carlo (MCMC) simulations were

228 run for 10 million generations with sampling intervals of 1,000 . Convergence of analyses and

229 adequacy of the sample sizes, with ESS values above 200 (ESS $=$ the number of effectively

230 independent draws from the posterior distribution that the Markov chain is equivalent to) were

231 confirmed in Tracer v.1.5. (Rambaut et al. 2013). Analyses were combined using LogCombiner

232 v.1.8.0, which is included within BEAST, after excluding the first $10 \%$ as burn-in. Obtained

233 trees were summarized in a maximum clade credibility tree using TreeAnotator v.1.8.0 and

234 visualized in FigTree v.1.4.0.

235 Species tree estimations

236 *BEAST estimates the species tree directly from the sequence data, nucleotide

237 substitution model parameters and the coalescent process (Heled and Drummond 2010). The

238 species trees were built by grouping all 235 sequences by putative species groups and

239 simultaneously estimating each of three individual gene trees (mt 16S-rDNA, ITS-rDNA and

240 ALG11), and the summary species trees using BEAST were drawn for two different species

241 model; (1) a six species model including P. tuberculosa, P. sp. yoron, P. mutuki, P. aff. mutuki,

242 P. sp. sakurajimensis sensu Reimer et al. (2007) and P. heliodiscus, and (2) a four species model 
243 combining $P$. sp. yoron with $P$. tuberculosa, and $P$. aff. mutuki with $P$. mutuki, along with $P$. sp.

244 sakurajimensis and $P$. heliodiscus.

245 All parameters were used as default except for; (1) the molecular clock rate, which was

246 changed to the log-normal relaxed model (Drummond et al. 2006), (2) the substitution rate for

$247 \mathrm{mt}$ 16S-rDNA, for which the range was calibrated to between 0.001-0.002/Mya based on the

248 reported substitution rate for mtCOI (Shearer et al. 2002), and (3) the substitution model for

249 ALG11 was modified to TPM1uf after generating the setting file. MCMC analyses were run for

250100 million generations with sampling intervals of 10,000 and excluding the first $10 \%$ as burn-

251 in. All the parameters in the output file were confirmed in Tracer v1.5. Obtained trees were

252 summarized in a maximum clade credibility tree using TreeAnotator v.1.8.0.

\section{Results}

254 Morphological analyses

255

The numbers of tentacles were measured for single randomly selected polyps from

256 eleven colonies of $P$. tuberculosa, eight colonies of $P$. sp. yoron, seven colonies of $P$. mutuki,

257 and eight colonies of $P$. aff. mutuki. The mean number of tentacles \pm standard deviation per

258 polyp was $31.6 \pm 3.4$ for $P$. tuberculosa, $40.5 \pm 2.6$ for $P$. sp. yoron, $54.4 \pm 7.4$ for $P$. mutuki, and

$25971.0 \pm 4.1$ for $P$. aff. mutuki. Each respective mean number of tentacles was significantly different

$260(\mathrm{p}<0.01)$ from all others in all pair tests (Table 3$).$

261

For cnidae, many subtle differences in sizes of the various types of cnidae present in

262 different tissues were present (Table 4; Fig. 3). However, the most obvious differences were in

263 small holotrichs, which were rarely observed in the tentacles of column of both $P$. aff. mutuki

264 and $P$. mutuki, and additionally observed in the tentacles and pharynx of $P$. aff. mutuki, but were

265 never observed in tissues of $P$. sp. yoron or $P$. tuberculosa (Table 4). However, these small 
266 holotrichs were only observed in one out of three specimens each of $P$. aff. mutuki and $P$. mutuki,

267 and thus no diagnostic differences were observed in the cnidae of all four species-groups 268 examined (Table 4).

269 In summary, we could clearly distinguish all four Palythoa species groups based on

270 tentacle numbers (Table 3), as well as gross external morphology (Fig. 2), but not via cnidae 271 analyses (Table 4).

272 Estimated spawning period

273 During the initial investigation of June to December in 2010, developed ovaries were 274 observed in P. tuberculosa from the middle of June to the middle of September with decreasing 275 numbers of polyps possessing ova (Fig. 4A, Table 6). Additionally, matured eggs were also 276 observed multiple times (on 28 July and 20 September). In contrast, developed ovaries and 277 matured eggs were observed (Fig. 5A, B) only one time (on 26 October) in P. sp. yoron. As well, 278 developing ovaries were observed in P. mutuki from the end of July to the middle of September, 279 however, no matured eggs were observed during this investigation.

280 In 2011, developed ovaries were observed in P. aff. mutuki on 15 June (Fig. 5E, F, Fig. 281 4B), and subsequently developed ovaries were observed in $P$. sp. yoron in early October and 282 early November (Fig. 5C, D), for the second consecutive year. On the other hand, no fully 283 developed ovaries were observed in P. tuberculosa and P. mutuki despite developing ovaries 284 being observed continuously during the summer season (on 23 July, 22 August and 5 October), 285 similar as observed in 2010.

286 Phylogenetic analyses

287 Molecular phylogenetic trees

$288 m t C O I$ 
290 sequence alignment is shown in Fig. 6A. Palythoa tuberculosa, $P$. sp. yoron, $P$. mutuki and $P$.

291 aff. mutuki formed one mixed clade with low bootstrap support (Maximum-Likelihood

$292[\mathrm{ML}]=<50 \%$, Neighbor-joining $[\mathrm{NJ}]=64 \%$, Bayes $[\mathrm{B}]=0.99)$. Three sequences of $P$. mutuki used

293 in previous research (Reimer et al. 2007; Reimer et al. 2011) formed one group with sequences

294 from $P$. sp. sakurajimensis.

$295 m t$ 16S-rDNA

The phylogenetic tree resulting from maximum likelihood analyses of the mt 16S-rDNA

297 sequence alignment is shown in Fig. 6B. Palythoa tuberculosa, $P$. sp. yoron, $P$. mutuki and $P$.

298 aff. mutuki formed one mixed clade with low bootstrap support $(\mathrm{ML}=65 \%, \mathrm{NJ}=64 \%, \mathrm{~B}<0.50)$.

299 Within this mixed clade, P. mutuki and $P$. aff. mutuki formed a mixed subclade with low

300 bootstrap support in ML and NJ analyses, however, this monophyletic clade was strongly

301 supported in Bayesian analyses $(\mathrm{ML}=64 \%, \mathrm{NJ}=64 \%, \mathrm{~B}=1.0)$. Additionally, two sequences of $P$.

302 mutuki from GenBank that were distinguished from other sequences of $P$. mutuki in previous

303 research (Reimer et al., 2006; AB219220, AB219221) formed a monophyletic subclade with

304 two novel sequences from this study (KX389366, KX389368; $\mathrm{ML}=64 \%, \mathrm{NJ}=63 \%, \mathrm{~B}=1.0)$.

305 ITS-rDNA

306

The phylogenetic tree resulting from maximum likelihood analyses of the ITS-rDNA

307 sequence alignment is shown in Fig. 6C. Palythoa tuberculosa and P. sp. yoron formed a very

308 well supported monophyletic clade $(\mathrm{ML}=95 \%, \mathrm{NJ}=99 \%, \mathrm{~B}=0.96)$. Within this clade were two

309 comparatively well supported sub-clades, one made by sequences obtained only from $P$. sp.

310 yoron sequences $(=\mathrm{KX} 389470, \mathrm{KX} 389471, \mathrm{DQ997921} ; \mathrm{ML}=90 \%, \mathrm{NJ}=99 \%, \mathrm{~B}=1.0)$, and the

311 other including three $P$. tuberculosa sequences (DQ997909, DQ997929, DQ997919; ML=70\%, 
$312 \mathrm{NJ}=83 \%, \mathrm{~B}=0.97)$. Palythoa mutuki was paraphyletic and two well supported clades that

313 included sequences from both $P$. mutuki and $P$. aff. mutuki were present (KX389473, KX389474,

$314 \mathrm{KX} 389475, \mathrm{KX} 389476, \mathrm{KX} 389481 ; \mathrm{ML}=93 \%, \mathrm{NJ}=99 \%, \mathrm{~B}=1.0$; and DQ997892, KX389479,

$315 \mathrm{KX} 389480, \mathrm{KX} 389483 ; \mathrm{ML}=72 \%, \mathrm{NJ}=77 \%, \mathrm{~B}=1.0)$.

$316 \quad A L G 11$

317 The phylogenetic tree resulting from maximum likelihood analyses of the ALG11

318 sequence alignment is shown in Fig. 6D. Compared to the above phylogenetic trees, this tree

319 was the most admixed, regardless of morphospecies. For example, sequences from $P$. sp.

320 sakurajimensis (used as outgroup here) appeared throughout the tree. Only three terminal clades

321 showed high bootstrap values (KX389373, KX389374, KX389379; $\mathrm{ML}=80 \%, \mathrm{NJ}=86 \%, \mathrm{~B}=1.0$;

322 and $\mathrm{KX} 389403, \mathrm{KX} 389422 ; \mathrm{ML}=90 \%, \mathrm{NJ}=95 \%, \mathrm{~B}=1.0 ;$ and $\mathrm{KX} 389414, \mathrm{KX} 389418$,

$323 \mathrm{KX} 389422 ; \mathrm{ML}=78 \%, \mathrm{NJ}=78 \%, \mathrm{~B}=1.0)$.

324 Topology comparison between trees

325 Examining the two outgroups used in this study, Palythoa sp. sakurajimensis was

326 phylogenetically much closer to $P$. tuberculosa, $P$. sp. yoron, P. mutuki and $P$. aff. mutuki

327 compared to $P$. heliodiscus in every gene tree. There were few differences in sequences from the

328 other four species groups, with only one base pair difference in the mtCOI tree, resulting in $P$. sp.

329 sakurajimensis' sequences forming one group with some P. mutuki specimens, and only one to

330 two base pairs' difference in the mt 16S-rDNA tree for all four species groups. In particular, in

331 the ALG11 tree, $P$. sp. sakurajimensis' sequences were admixed with the other four species 332 groups.

333 Palythoa tuberculosa and P. sp. yoron (designated as the "Palythoa tuberculosa group"

334 here), and P. mutuki and P. aff. mutuki (designated as "Palythoa mutuki group" here) did not 
335 separate into four species groups in each DNA marker's tree. The P. tuberculosa group formed a

336 monophyletic clade in the ITS-rDNA tree and one grouping in the mt 16S-rDNA gene tree with

337 one base difference from the P. mutuki group. On the other hand, the P. mutuki group did not

338 show any common pattern, i.e. admixed with all other species groups except for P. heliodiscus

339 in the ALG11 gene tree, most sequences forming one monophyletic clade with the $P$.

340 tuberculosa group due to no differences in sequences with some sequences forming one group

341 with $P$. sp. sakurajimensis due to a one base pair difference from other specimens in the mtCOI

342 tree, forming a monophyletic clade with one subclade in the mt 16S-rDNA tree, and forming a

343 paraphyletic clade with a monophyletic subclade of P. tuberculosa in the ITS-rDNA tree.

344 Species trees

345 All hypothetical species were fully supported with posterior probability under both the

346 four and six species models (Fig. 7A, B). The divergence time from the most recent common

347 ancestor of $P$. tuberculosa, $P$. sp. yoron, $P$. mutuki and $P$. aff. mutuki, (divergence of $P$. sp.

348 sakurajimensis in both cases), was calculated as 147,000 years before present with $95 \%$ credible

349 interval [lower 30,900 - upper 292,000] under the six species model and as 113,000 years under

350 the four species model with $95 \%$ credible interval [lower 25,500 - upper 231,000].

\section{Discussion}

The purpose of this study was to re-evaluate the systematics of some Palythoa species

using an integrative approach. Primary hypotheses of species delimitation were based on external

354 morphology (phenetic criterion) and habitat preferences (ecological criterion). These hypotheses

355 were then examined in the light of additional characters, namely the number of tentacles, 356 spawning periods and genetic data. 
The mean numbers of tentacles were significantly different among specimens of the four

359 putative species; P. tuberculosa, $P$. sp. yoron, $P$. mutuki and $P$. aff. mutuki (Table 3). However,

360 in previous research, the tentacle number of $P$. tuberculosa has been reported as various ranges,

361 i.e. 30 to 40 (Klunzinger 1877), up to 50 (Walsh and Bowers 1971), 38 to 52 (Reimer and Todd

362 2009), 30 to 37 (Shiroma and Reimer 2010), or 30 to 50 (Hibino et al. 2013). A wider range of

363 variations has been reported in P. mutuki, with 88 to 144 (Ryland and Lancaster 2003), 60 to 74,

364 approximately 80 for P. mutuki-related (Reimer and Todd 2009), or 42 to 66 (Shiroma and

365 Reimer 2010) reported. Thus, the ranges of tentacle numbers can be assumed to be 30 to 52 for

366 P. tuberculosa and 42 to 144 for $P$. mutuki, and therefore tentacle numbers of $P$. sp. yoron and $P$.

367 aff. mutuki observed in this study are within ranges of previously reported intraspecific variation.

368 These differences between tentacle numbers reported in the literature and our data may be partly

369 explained by the fact that previous authors did not consider $P$. sp. yoron and $P$. aff. mutuki as 370 different species.

371 However, Ong et al. (2013) also demonstrated phenotypic plasticity in P. tuberculosa

372 with high ability to acclimate against changes in light-induced environments. From in situ

373 observations, $P$. sp. yoron seems to prefer locations exposed to strong current such as extensive

374 reef flats where the back reef moat is widely developed. Correspondingly, $P$. sp. yoron is also

375 often found in back reef moats, as Shiroma and Reimer (2010) mentioned, covered with sand or

376 other loose detritus. High numbers of tentacles enable them to acquire nutritious detritus and

377 feed on planktonic organisms, but strong-current environments repeatedly cover colonies with

378 sand. From the viewpoint of its small, tetrapod colony shape, $P$. sp. yoron seems have adapted to

379 such an environment. Therefore, to ensure whether differences in tentacle numbers and colony 
380 form between $P$. tuberculosa and $P$. sp. yoron are caused by species differentiation, the

381 observation of reaction norms of each species with transplantation experiments is needed.

382 Although previous cnidae research with detailed statistical analyses revealed finer-scale

383 differences among Palythoa species (Ryland and Lancaster 2004), we did not observe any useful

384 diagnostic differences with utility for rapid identification of species groups in this study.

385 Spawning periods and reproductive isolation

Over the two years analyzed, $P$. sp. yoron consistently developed ovaries later than the

387 three other putative species. If we assume a sharp drop in the proportion of developed ovaries as

388 the consequence of the release of eggs, the annual spawning period estimated for $P$. sp. yoron

389 was early to mid-November and that of $P$. aff. mutuki mid- to late June. The spawning period of

390 P. tuberculosa in Okinawa-jima I. has been reported in early August (Yamazato et al. 1973),

391 from the end of July to middle August (Shiroma and Reimer 2010), and on 19 and 20 August in

3922009 (Hirose et al. 2011). In our study, spawning was estimated to have occurred in August in

3932010 and possibly from early July in 2011. The reproductive season of $P$. mutuki was presumed

394 that be synchronized with $P$. tuberculosa in 2010, although developed eggs were not confirmed.

395 Little is known about the sexual reproductive ability of this species, and according to Ryland and

396 Lancaster (2003) the only previous records of $P$. mutuki possessing developed oocytes are from

397 Fiji and Tuvalu. To overcome this lack of knowledge, closer examinations via staging of

398 histological sections for gonadal development (such as done by Polak et al. 2011) are required.

399 Interpreting these results in terms of putative reproductive isolation is not straightforward.

400 Even assuming that a sharp drop in the proportion of developed ovaries translates into a major

401 spawning event, which seems to be a reasonable hypothesis, this does not exclude the

402 possibility of eggs being released much later than the initial peak. For example, while we 
403 estimated the spawning period of P. tuberculosa to have occurred in August in 2010, nearly 20\%

404 of individuals still had developing or developed ovaries on September $20^{\text {th }}$, which may have

405 been released as mature eggs at any time from then until October $26^{\text {th }}$ (Fig. 4A), and enabled

406 potential cross-fertilization with $P$. sp. yoron. On the other hand, data thus far indicate spawning

407 on one or two nights per year for brachycneminic zoantharians (Ryland 1997), and reabsorption

408 of oocytes (Ono et al. 2005) that did not spawn. More work is needed to determine exact

409 spawning patterns of Palythoa tuberculosa and closely Palythoa related species, but the

410 asynchrony of both ovary development ( $P$. sp. yoron) and spawning peaks for $P$. tuberculosa

411 and $P$. aff. mutuki suggest that at least partial pre-zygotic reproductive isolation is possible

412 among $P$. sp. yoron, P. tuberculosa and $P$. aff. mutuki at Tokunoshima I.

413 Species boundaries in phylogenetic trees

414 The four genetic markers analyzed in this study displayed contrasting patterns. The two

415 mitochondrial genes were relatively conservative, as has been reported for other anthozoans

416 (Shearer et al. 2002; Huang et al. 2008), but $\mathrm{mt}$ 16S-rDNA allowed the recovery of $P$.

417 heliodiscus, $P$. sp. sakurajimensis, the $P$. mutuki group and the $P$. tuberculosa group as four

418 genetically homogeneous groups (phenetic criterion), and all species or species groups were

419 reciprocally monophyletic with the exception of $P$. tuberculosa. ITS-rDNA showed a similar

420 pattern with the $P$. mutuki group and the $P$. tuberculosa group represented in distinct clades,

421 although the P. mutuki group was paraphyletic. This consistency across mitochondrial and

422 nuclear markers also suggests that there is no genetic exchange (biologic criterion) between

423 these four groups, and thus provides a first level of species delimitation. In contrast, all Palythoa

424 spp. besides $P$. heliodiscus were largely mixed in the tree recovered from the ALG11 marker,

425 which strongly suggests incomplete lineage sorting for this gene. 
Despite obvious differences in morphology and reproductive season between $P$.

427

428

429

430

431

432

433

434

435

436

tuberculosa and $P$. sp. yoron, as well between $P$. mutuki and $P$. aff. mutuki, no molecular marker

was successful in dividing these species pairs into their own monophyletic clades. Palythoa sp. yoron formed a subclade from two specimens in Reimer et al. (2007a), however, in this study reconstructing phylogenetic trees based on the same genomic region with more specimens of $P$. sp. yoron, one mixed monophyletic clade was supported well with all the other $P$. tuberculosa specimens. The same pattern was observed with $P$. mutuki and $P$. aff. mutuki. These results imply either gene flow between each pair of nominal species or incomplete lineage sorting. Although these two alternative hypotheses are not mutually exclusive, the absence of intermediate morphotypes and the presence of distinct spawning periods lead us to favor the latter over extensive gene flow. Sequences from other single-copy nuclear markers like ALG11 are required to more thoroughly resolve these two species pairs.

\section{Sympatric speciation timing}

Recently, sympatric speciation has come to be understood as a major generator of marine biodiversity (reviewed in Bowen et al. 2013). Under such situations, ecological (e.g. behavior or microhabitat) boundaries lead to isolation. However, the hierarchy of timing of sympatric speciation processes (e.g. the order that separation occurs via phylogenetic, reproductive, and morphological criteria) as lineages diverge remains not well understood, with no clear consensus (Norris and Hull 2012; Pabijan et al. 2017). For example, in tropical bivalves, phylogenetic differences (=cryptic species) have been observed without any clear evidence of morphological differences (e.g. Lemer et al. 2014). On the other hand, in many marine taxa, it has been proposed that during sympatric speciation, reproductive isolation is one driving force behind lineage divergence (Palumbi 1994). 
In this study, morphology and reproductive data sets showed four Palythoa lineages, 450 while DNA markers showed either two lineages (ITS-rDNA, mtCOI, mt 16S-rDNA) or one 451 admixed lineage (ALG11). Combined molecular analyses suggested either two or four lineages 452 were equally possible (Fig. 7). Such varied results along a speciation continuum between 453 different datasets reflect the patterns to be expected during ongoing or incomplete speciation 454 events (Nosil et al. 2009). As all four Palythoa lineages can be found in sympatry at Tokushima 455 I., our results suggest that reproductive isolation, perhaps caused by past hybridization and back456 crossing events (Reimer et al. 2007a; MacLeod et al. 2015), led to the generation of these 457 different lineages and morphological differentiation. Phylogenetic differentiation currently remains incomplete due to the evolutionary recentness of these events, estimated as less than 200,000 years before present. Such confounding data, with reproductive isolation but incomplete genetic lineage sorting, can be expected due to the extended duration of speciation events (Norris and Hull 2012).

\section{Conclusions}

Overall, the data imply that Palythoa species have a much more complex evolutionary

464 history at the species level than previously expected (e.g. in Reimer et al. 2007a). However, 465 natural hybridization between $P$. tuberculosa, $P$. sp. yoron and $P$. aff. mutuki seems to not be 466 currently occurring, at least for populations at Tokunoshima I. observed in this study. In spite of 467 ambiguous phylogenetic differentiation between $P$. tuberculosa and $P$. sp. yoron, and between $P$. $468 m u t u k i$ and $P$. aff. mutuki, we consider these four lineages are all distinct species based on their 469 morphological differentiation and distinct spawning periods. In situ observation of spawning 470 events combined with genomic level examinations will help further clarify the hierarchy of 
471 timing in speciation events, and these four sympatric Palythoa lineages present a potential model 472 system for such studies. 


\section{Acknowledgements}

474 The authors sincerely thank Dr. D. Albinsky (University of the Ryukyus, UR) for technical 475 help during molecular experiments. The people of Tokunoshima I. are thanked for help during

476 field surveys. As well, thanks to Dr. M. Obuchi and Dr. A. Iguchi (both UR), who both spared 477 much time for discussion of statistical analyses. Dr. M. Maronna (U. Sao Paolo) is thanked for 478 comments on alignments. Finally, MISE Laboratory members are thanked for their support. 479 Comments from three reviewers and the editor greatly improved an earlier version of this 480 manuscript. 


\section{References}

482 Belinky F, Szitenberg A, Goldfarb I, Feldstein T, Wörheide G, Ilan M, Huchon D. 2012. 483 ALG11 - A new variable DNA marker for sponge phylogeny: comparison of phylogenetic 484 performances with the 18S rDNA and the COI gene. Molecular Phylogenetics and Evolution 63: $485702-713$.

486 Bowen BW, Rocha LA, Toonen RJ, Karl SA, ToBo Laboratory. 2013. The origins of 487 tropical marine biodiversity. Trends in Ecology and Evolution 28: 359-366.

488 Darriba D, Taboada GL, Doallo R, Posada D. 2012. jModelTest 2: more models, new 489 heuristics and parallel computing. Nature Methods 9:8, 772.

490 Drummond AJ, Suchard MA, Xie D, Rambaut A. 2010. Bayesian phylogenetics with 491 BEAUti and the BEAST 1.7. Molecular Biology and Evolution. 29: 1969-1973. DOI: $49210.1093 / \mathrm{molbev} / \mathrm{mss} 075$.

493 Drummond AJ, Ho SY-W, Phillips MJ, Rambaut A. 2006 Relaxed phylogenetics and 494 dating with confidence. PLOS Biology 4: 699-710. DOI: 10.1371/journal.bio.0040088.

495 England KW. 1991. Nematocysts of sea anemones (Actiniaria, Ceriantharia and 496 Corallimorpharia: Cnidaria): nomenclature. Hydrobiologia 216/217: 691-697. DOI: $497 \quad 10.1007 / \mathrm{BF} 00026532$

498 Felsenstein J. 1985. Confidence limits on phylogenies: an approach using the bootstrap. 499 Evolution 39: 783-791.

500 Folmer O, Black M, Hoeh W, Lutz R, Vrijenhoek R. 1994. DNA primers for amplification 501 of mitochondrial cytochrome c oxidase subunit I from diverse metazoan invertebrates. 502 Molecular Marine Biology and Biotechnology 3: 294-299. 
503 Guindon S, Gascuel O. 2003. A simple, fast, and accurate algorithm to estimate large

504 phylogenies by maximum likelihood. Systematic Biology 52: 696-704.

505 Hall TA. 1999. BioEdit: a user-friendly biological sequence alignment editor and analysis 506 program for Windows 95/98/NT. Nucleic Acids Symposium Series 41: 95-98.

Hatta M, Fukami H, Wang W, Omori M, Shimoike K, Hayashibara T, Ina Y, Sugiyama T. 1999. Reproductive and genetic evidence for a reticulate evolutionary history of mass-spawning 509 corals. Molecular Biology and Evolution 16: 1607-1613.

Heled J, Drummond AJ. 2010. Bayesian inference of species trees from multilocus data.

511 Molecular Biology and Evolution 27: 570-580.

512 Hibino Y, Todd PD, Yang S, Benayahu Y, Reimer JD. 2013. Molecular and

513 morphological evidence for conspecificity of two common Indo-Pacific species of Palythoa

514 (Cnidaria: Anthozoa). Hydrobiologia 733: 31-43. DOI: 10.1007/s10750-013-1587-5

515 Hill MS, Hill AL, Lopez J, Peterson KJ, Pomponi S. 2013 Reconstruction of family-level 516 phylogenetic relationships within Demospongiae (Porifera) using nuclear encoded housekeeping 517 genes. PLoS ONE 8: e50437. DOI: 10.1371/journal.pone.0050437.

518 Hirose M, Obuchi M, Hirose E, Reimer JD. 2011. Timing of spawning and early 519 development of Palythoa tuberculosa (Anthozoa, Zoantharia, Sphenopidae) in Okinawa, Japan. 520 Biological Bulletin 220: 23-31.

521 Huang D, Meier R, Todd PA, Chou LM. 2008. Slow mitochondrial COI sequence 522 evolution at the base of the metazoan tree and its implications for DNA barcoding. Journal of 523 Molecular Evolution 66: 167-174. 
525 morphologically distinct species of Acropora (Cnidaria, Scleractinia) in the Pacific: fertilization 526 and larval survival rates. PLoS ONE 8: e56701. DOI: 10.1371/journal.pone.0056701.

527 Irei Y, Nozawa Y, Reimer JD. 2011. Distribution patterns of five zoanthid species at 528 Okinawa Island, Japan. Zoological Studies 50: 426-433.

529 Kimura S, Hashimoto Y. 1972. Toxicity of the zoanthid Palythoa tuberculosa. Toxicon 530 10: 611-617.

531 Klunzinger KB. 1877. Die Korallthiere des Rothen Meeres. 1: Die Alcyonarien und

532 Malacodermen. Verlag der Gutmann'schen Buchhandlung (Otto Enslin), Berlin (in German and 533 Latin).

534 Leache AD, Fujita MK. 2010. Bayesian species delimitation in West African forest geckos 535 (Hemidactylus fasciatus). Proceeding of the Royal Society B 277: 3071-3077. DOI: $53610.1098 /$ rspb.2010.0662.

537 Lemer S, Buge B, Bemis A, Giribet G. 2014. First molecular phylogeny of the 538 circumtropical bivalve family Pinnidae (Mollusca, Bivalvia): Evidence for high levels of cryptic 539 species diversity. Molecular Phylogenetics and Evolution 75: 11-23.

540 MacLeod A, Rodríguez A, Vences M, Orozco-terWengel P, García C, Trillmich F, Gentile

541 G, Caccone A, Quezada G, Steinfartz S. 2015. Hybridization masks speciation in the 542 evolutionary history of the Galápagos marine iguana. Proceedings of the Royal Society B 282:

543 20150425. http://dx.doi.org/10.1098/rspb.2015.0425

544 Mayr E, 1957. Species concepts and definitions. in E. Mayr (ed.), The Species Problem, 545 American Association for the Advancement of Science Publication, 50. 
547 Atlantic reef zoanthid Palythoa caribaeorum. Bulletin De L'institut Oceanographique (Monaco) 548 14: 89100.

549 Muirhead A, Ryland JS. 1985. A review of the genus Isaurus Gray 1828 (Zoanthidea), 550 including new records from Fiji. Journal of Natural History 19: 323-335.

551 Nosil P, Harmon LJ, Seehausen O. 2009. Ecological explanations for (incomplete) 552 speciation. Trends in Ecology and Evolution 24: 145-156.

553 Norris RD, Hull PM. 2011. The temporal dimension of marine speciation. Evolutionary 554 Ecology 26: 393-415.

555 Ohki S, Kowalski RK, Kitanobo S, Morita M. 2015. Changes in spawning time led to the 556 speciation of the broadcast spawning corals Acropora digitifera and the cryptic species 557 Acropora sp. 1 with similar gamete recognition systems. Coral Reefs 34: 1189-1198. DOI $558 \quad 10.1007 / \mathrm{s} 00338-015-1337-4$

559 Ong CW, Reimer JD, Todd PA. 2013. Morphologically plastic responses to shading in the 560 zoanthids Zoanthus sansibaricus and Palythoa tuberculosa. Marine Biology 160: 1053-1064 561 DOI: $10.1007 / \mathrm{s} 00227-012-2158-4$.

562 Pabijan M, Zieliński P, Dudek K, Stuglik M, Babik W. 2017. Isolation and gene flow in a 563 speciation continuum in newts. Molecular Phylogenetics and Evolution 116: 1-12.

564 Palumbi SR. 1994. Genetic divergence, reproductive isolation, and marine speciation. 565 Annual Revue of Ecology and Systematics 25: 547-572

566 Polak O, Loya Y, Brickner I, Kramarski-Winter E, Benayahu Y. 2011. The widely567 distributed Indo-Pacific zoanthid Palythoa tuberculosa: a sexually conservative strategist. 568 Bulletin of Marine Science 87: 605-621. 
Posada D 2008. jModelTest: phylogenetic model averaging. Molecular Biology and 570 Evolution 25: 1253-1256.

571 Putron SJ, Ryland JS. 2009. Effect of seawater temperature on reproductive seasonality

572 and fecundity of Pseudoplexaura porosa (Cnidaria: Octocorallia): latitudinal variation in 573 Caribbean gorgonian reproduction. Invertebrate Biology 128: 213-222.

574 Rambaut A, Suchard MA, Xie D, Drummond AJ. 2013, Tracer v1.5. Available from 575 http://beast.bio.ed.ac.uk/Tracer.

576 Rasband WS. 2012. ImageJ: Image processing and analysis in Java. Astrophysics Source 577 Code Library 1: 6013.

578 Reimer JD. 2010. Key to field identification of shallow water brachycnemic zoanthids 579 (Order Zoantharia: Suborder Brachycnemina) present in Okinawa. Galaxea, Journal of Coral 580 Reef Studies 12: 23-29.

581 Reimer JD, Hirose M, Yanagi K, Sinniger F. 2011. Marine invertebrate diversity in the 582 oceanic Ogasawara Islands: a molecular examination of zoanthids (Anthozoa: Hexacorallia) and 583 their Symbiodinium (Dinophyceae). Systematics and Biodiversity 9: 133-43.

584 Reimer JD, Nakachi S, Hirose S, Hirose E, Hashiguchi S. 2010. Using hydrofluoric acid 585 for morphological investigations of zoanthids (Cnidaria: Anthozoa): A critical assessment of 586 methodology and necessity. Marine Biotechnology 12: 605-617. DOI 10.1007/s 10126-0099249$587 \quad 3$

588 Reimer JD, Ono S, Fujiwara Y, Takishita K, Tsukahara J. 2004. Reconsidering Zoanthus 589 spp. diversity: Molecular evidence of conspecifity within four previously presumed species. 590 Zoological Science 21: 517-525. 
591 Reimer JD, Takishita K, Maruyama T. 2006. Molecular identification of symbiotic 592 dinoflagellates (Symbiodinium spp.) from Palythoa spp. (Anthozoa: Hexacorallia) in Japan. 593 Coral Reefs 25: 521-527.

594 Reimer JD, Takishita K, Ono S, Maruyama T. 2007a. Diversity and evolution in the 595 zoanthid genus Palythoa (Cnidaria: Hexacorallia) based on nuclear ITS-rDNA. Coral Reefs 26: 596 399-410. DOI 10.1007/s00338-007-0210-5.

597 Reimer JD, Takishita K, Ono S, Tsukahara J, Maruyama T. 2007b. "Molecular evidence 598 suggesting interspecific hybridization in Zoanthus spp. (Anthozoa: Hexacorallia). Zoological 599 Science 24: 346-359.

600 Reimer JD, Todd PA. 2009. Preliminary molecular examination of zooxanthellate zoanthid 601 (Hexacorallia, Zoantharia) and associated zooxanthellae (Symbiodinium spp.) diversity in 602 Singapore. Raffles Bulletin of Zoology 22: 103-120.

603 Reimer JD, Irei Y, Fuji T, Yang S-Y. 2013. Molecular analyses of shallow-water 604 zooxanthellate zoanthids (Cnidaria: Hexacorallia) from Taiwan and their Symbiodinium spp. 605 Zoological Studies 52: 38.

606 Ryland JS. 1997. Reproduction in Zoanthidea (Anthozoa: Hexacorallia). Invertebrate 607 Reproduction and Development 31: 177-188.

608 Ryland JS. 2000. Reproduction in British zoanthids, and an unusual process in 609 Parazoanthus anguicomus. Journal of the Marine Biological Association of the United Kingdom 610 80: 943-944.

611 Ryland JS, Lancaster JE. 2003. Revision of methods of separating species of 612 Protopalythoa (Hexacorallia: Zoanthidea) in the tropical West Pacific. Invertebrate Systematics 613 17: 407-428. 
614 Ryland JS, Lancaster JE. 2004. A review of zoanthid nematocyst types and their 615 population structure. Hydrobiologia 530(1/3): 179-187. DOI: 10.1007/s10750-004-2685-1

616 Shearer TL, Oppen MJH, Romano SL, Worheide GW. 2002. Slow mitochondrial DNA 617 sequence evolution in the Anthozoa (Cnidaria). Molecular Ecology 11: 2475-2487.

618 Shiroma E, Reimer JD. 2010. Investigations into the reproductive patterns, ecology, and 619 morphology in the zoanthid genus Palythoa (Cnidaria: Anthozoa: Hexacorallia) in Okinawa, 620 Japan. Zoological Studies 49: 182-194.

621 Sinniger F, Montoya-Burgos JI, Chevaldonn'e P, Pawlowski J. 2005. Phylogeny of the 622 order Zoantharia (Anthozoa, Hexacorallia) based on the mitochondrial ribosomal genes. Marine 623 Biology 147: 1121-1128.

624 Sperling EA, Pisani D, Peterson KJ. 2007. Poriferan paraphyly and its implications for 625 Precambrian palaeobiology. Geological Society London Special Publications 286: 355-368.

626 Stephens M, Scheet P. 2005. Accounting for decay of linkage disequilibrium in haplotype 627 inference and missing-data imputation. American Journal of Human Genetics 76:449-462.

628 Stephens M, Smith N, Donnelly P. 2001. A new statistical method for haplotype 629 reconstruction from population data. American Journal of Human Genetics 68: 978-989.

630 Swain TD. 2010. Evolutionary transitions in symbioses: dramatic reductions in bathymetric 631 and geographic ranges of Zoanthidea coincide with loss of symbioses with invertebrates.

632 Molecular Ecology 19: 2587-2598.

633 Tamura K, Peterson D, Peterson N, Stecher G, Nei M, Kumar S. 2011. MEGA5: Molecular 634 Evolutionary Genetics Analysis using maximum likelihood, evolutionary distance, and 635 maximum parsimony methods. Molecular Biology and Evolution 28: 2731-2739. 
637 progressive multiple sequence alignment through sequence weighting, position-specific gap 638 penalties and weight matrix choice. Nucleic Acids Research 22: 4673-4680.

639 Trench RK. 1974. Nutritional potentials in Zoanthus sociatus (Coelenterata, Anthozoa). 640 Helgoländer wissenschaftliche Meeresuntersuchungen 26: 174-216.

641 Vollmer S, Palumbi S. 2002. Hybridization and the evolution of reef coral diversity. 642 Science 296: 5575, 2023-2025. DOI: 10.1126/science.1069524.

643 Yamazato K, Yoshimoto F, Yoshihara N. 1973. Reproductive cycle in a zoanthid Palythoa 644 tuberculosa Esper. Publications of the Seto Marine Biological Laboratory 20:275-283.

645 Walsh GE, Bowers RL. 1971. A review of Hawaiian zoanthids with descriptions of three 646 new species. Zoological Journal of the Linnaean 50: 161-180. DOI: 10.1111/j.10963642.1971.tb00757.x

648

649

650 Figure legends

651 Fig. 1. Map of Palythoa species specimen locations in the Ryukyu Archipelago, including 652 Okinawa-jima Island, Zamami-jima Island, Yoron-to Island, Okinoerabu-jima Island, and 653 Tokunoshima Island. Locations for specimens collected in this study represented by closed 654 symbols, location for spawning timing investigations represented by open symbol. 655

656 Fig. 2 In situ images of A Palythoa tuberculosa, B P. mutuki, C P. sp. yoron, D P. aff. mutuki, E 657 P. tuberculosa (left; "Pt") and P. sp. yoron (right, "Py"), and F P. mutuki (left, "Pm") and P. aff. 
658 mutuki (right, "Pam"). Scale bars in $\mathbf{A}, \mathbf{C}, \mathbf{E}$ are $2 \mathrm{~cm}$, in B, D, F $1 \mathrm{~cm}$. All images taken by M.

659 Mizuyama.

660

661 Fig. 3 - Cnidae in tentacles, column, pharynx, and filaments of Palythoa aff. mutuki, Palythoa 662 mutuki, Palythoa sp. yoron, and Palythoa tuberculosa. S = spirocysts, $\mathrm{B}=$ basitrichs, HS = 663 holotrichs small, $\mathrm{HL}=$ holotrichs large, $\mathrm{P}=$ microbasic $\mathrm{p}$-mastigophores.

664

665 Fig. 4A. Monthly change of ratio of number of polyps possessing developing and/or developed 666 ovaries $(\mathrm{N})$ on total number of examined polyps $(\mathrm{Nt})$ in 2010 . Red, P. tuberculosa; blue, $P$.

667 mutuki; yellow, P. sp. yoron. B. Monthly change of ratio of number of polyps possessing 668 developing and/or developed ovaries (N) on total number of examined polyps (\%) in 2011. Red, 669 P. tuberculosa; blue, P. mutuki; yellow, P. sp. yoron; green, P. aff. mutuki.

670

671 Fig. 5 Cross section of polyp of A Palythoa sp. yoron (26 October 2010) and B matured eggs; C 672 P. sp. yoron (9 November 2011) and D germinal ribbon inside a mesentery; E $P$. aff. mutuki (21 673 June 2011), and F developed ovaries. Abbreviations: te, tentacles; od, oral disk; co, 674 coenenchyme; mo, mouth; ph, pharynx; eg, eggs; mf, mesenterial filament; gr, germinal ribbon; 675 ov, ovary. Scale bars: $2 \mathrm{~mm}$ in $\mathbf{A}$ and $\mathbf{E} ; 500 \mu \mathrm{m}$ in $\mathbf{B} ; 1 \mathrm{~mm}$ in $\mathbf{C}, \mathbf{D}$ and $\mathbf{F}$. All images taken by 676 M. Mizuyama.

677

678 Fig. 6A. Maximum likelihood (ML) tree of cytochrome oxidase subunit I (COI) sequences. B. 679 ML tree of mitochondrial 16S ribosomal DNA (mt 16S-rDNA) sequences. C. Maximum 680 likelihood tree of internal transcribed spacer of ribosomal DNA (ITS-rDNA) sequences. D. 
681 Maximum likelihood tree of asparagine-linked glycosylation 11 protein (ALG11) region. Values

682 at branches represent $\mathrm{ML}$ and $\mathrm{NJ}$ bootstrap probabilities, respectively ( $>50 \%$ ). Bayesian 683 posterior probabilities of $>0.95$ are represented by thick branches. Sequences from specimens 684 identified as Palythoa heliodiscus indicated by light purple circles, from $P$. sp. sakurajimensis as 685 dark purple, from $P$. mutuki as dark blue, from $P$. aff. mutuki as green, from $P$. sp. yoron as 686 yellow, and from P. tuberculosa as red. GenBank accession numbers of sequences generated in 687 this study in bold. For specimen information, please see Tables 2 (for novel sequences) and 5 688 (for previously reported sequences).

689

690 Fig. 7 Species trees for Palythoa under A. six species model, and B. four species model. Values 691 at branches represent upper and lower limits of demographic time under the coalescent model. 692 693 Tables

694 Table 1. Characters employed for identification of Palythoa species. 695

696 Table 2. Examined Palythoa specimens in this study.

697

698 Table 3. The mean number of tentacles \pm standard deviation and results of Mann-Whitney U test 699 with Bonferroni correction between each Palythoa species pairs. $\mathrm{N}=$ total number of examined 700 polyps for each species (one per colony).

701

702 Table 4. Cnidae types and sizes of Palythoa aff. mutuki, Palythoa mutuki, Palythoa sp. yoron 703 and Palythoa tuberculosa. Frequency: relative abundance of cnidae type in decreasing order; 
704 numerous, common, occasional, rare, very rare $(\mathrm{N}=$ number of specimens found/total 705 specimens examined).

706

707 Table 5. GenBank accession numbers of genus Palythoa sequences from previous studies used 708 in this study's phylogenetic analyses.

709

710 Table 6. Number of polyps possessing developing and/or developed ovaries $(\mathrm{N})$, total number of

711 examined polyps (Nt) and ratio of $\mathrm{N}$ to $\mathrm{Nt}$ for collected specimens of P. tuberculosa, P. mutuki,

$712 P$. sp. yoron and $P$. aff. mutuki on each sampling date. *indicates observation of developed 713 ovaries in specimens. 


\section{Table 1 (on next page)}

Characters employed for identification of Palythoa species. 
1 Table 1. Characters employed for identification of Palythoa species.

\begin{tabular}{|c|c|c|c|c|}
\hline Species & P. tuberculosa & $P$. sp. yoron & P. mutuki & $P$. aff. mutuki \\
\hline Typical environment & $\begin{array}{c}\text { Backreef moat - out } \\
\text { reef }\end{array}$ & Reef flat, tide pool & $\begin{array}{c}\text { Reef flat, reef edge, } \\
\text { surge channel }\end{array}$ & Reef flat, reef edge, \\
\hline $\begin{array}{l}\text { Coenenchyme } \\
\text { development }\end{array}$ & Well-developed & $\begin{array}{r}\text { Moderately } \\
\text { developed }\end{array}$ & $\begin{array}{c}\text { Not well developed; } \\
\text { or stoloniferous }\end{array}$ & $\begin{array}{c}\text { Not well developed; } \\
\text { or stoloniferous }\end{array}$ \\
\hline Polyp structure & $\begin{array}{c}\text { immersae } \\
\text { (= “embedded") }\end{array}$ & $\begin{array}{c}\text { intermediae } \\
\text { (= "moderate") }\end{array}$ & $\begin{array}{c}\text { liberae } \\
\text { (= “free-standing") }\end{array}$ & $\begin{array}{c}\text { liberae } \\
\text { (= "free-standing") }\end{array}$ \\
\hline $\begin{array}{l}\text { Surface structure of } \\
\text { capitular ridges }\end{array}$ & Smooth & Smooth & Jagged & Smooth \\
\hline $\begin{array}{c}\text { Number of } \\
\text { polyps/colony }\end{array}$ & $>10$ & $<10$ & $>10$ & $>10$ \\
\hline
\end{tabular}




\section{Table 2 (on next page)}

Examined Palythoa specimens in this study from the Ryukyu Archipelago. 
1 Table 2. Examined Palythoa specimens in this study.

2

\begin{tabular}{|c|c|c|c|c|c|c|c|c|c|c|}
\hline $\begin{array}{l}\text { Specimen } \\
\text { code }\end{array}$ & Location/Region & $\begin{array}{l}\text { GPS } \\
\text { code }\end{array}$ & Species ID & Date $(\mathrm{m} / \mathrm{d} / \mathrm{y})$ & $\begin{array}{c}\text { Collected } \\
\text { by }\end{array}$ & Fixed by & $\mathrm{mt} \mathrm{COI}$ & $\begin{array}{l}\text { mt 16S- } \\
\text { rDNA }\end{array}$ & ITS-rDNA & ALG11 \\
\hline 2PtOkOd & Odo/Okinawa & 1 & P. tuberculosa & Aug 18.09 & $\mathrm{MM}^{*}{ }_{1}$ & $99.5 \% \mathrm{EtOH}$ & NA & NA & NA & KX389373 \\
\hline 4PtOkOd & Odo/Okinawa & 1 & P. tuberculosa & Aug 23.09 & MM & $99.5 \% \mathrm{EtOH}$ & NA & KX389335 & NA & KX389374 \\
\hline 5PtOkOd & Odo/Okinawa & 1 & P. tuberculosa & Aug 23. 09 & MM & $99.5 \% \mathrm{EtOH}$ & NA & NA & NA & KX389375 \\
\hline 37PtYoMa & Maehama/Yoron & 2 & P. tuberculosa & Mar 03. 10 & $\mathrm{JDR}^{* 2}$ & $99.5 \% \mathrm{EtOH}$ & NA & KX389336 & NA & KX389376 \\
\hline 39PtYoUk & Ukachi/Yoron & 3 & P. tuberculosa & Mar 04. 10 & MM & $99.5 \% \mathrm{EtOH}$ & NA & KX389337 & KX389459 & KX389377 \\
\hline 40PtYoUk & Ukachi/Yoron & 3 & P. tuberculosa & Mar 04. 10 & MM & $99.5 \% \mathrm{EtOH}$ & NA & NA & NA & KX389378 \\
\hline 49PtYoUk & Ukachi(West)/Yoron & 4 & P. tuberculosa & Mar 04. 10 & MM & $99.5 \% \mathrm{EtOH}$ & NA & NA & NA & KX389379 \\
\hline 63PtErYa & Yakomo/Okinoerabu & 5 & P. tuberculosa & Mar 05. 10 & MM & $99.5 \% \mathrm{EtOH}$ & NA & KX389338 & NA & KX389380 \\
\hline 65PtErYa & Yakomo/Okinoerabu & 5 & P. tuberculosa & Mar 05. 10 & MM & $99.5 \% \mathrm{EtOH}$ & NA & NA & NA & KX389381 \\
\hline 91PtToYo & Yonama/Tokunoshima & 6 & P. tuberculosa & Mar 08. 10 & MM & $99.5 \% \mathrm{EtOH}$ & NA & NA & NA & KX389382 \\
\hline 98PtToKa & Kaminomine/Tokunoshima & 7 & P. tuberculosa & Mar 09. 10 & MM & $99.5 \% \mathrm{EtOH}$ & NA & NA & NA & KX389383 \\
\hline 100PtToKa & Kaminomine/Tokunoshima & 7 & P. tuberculosa & Mar 09. 10 & MM & $99.5 \% \mathrm{EtOH}$ & NA & KX389339 & NA & KX389384 \\
\hline 358PtOkAk & Akazaki/Okinawa & 8 & P. tuberculosa & Jun 24. 12 & MM & $99.5 \% \mathrm{EtOH}$ & NA & KX389340 & NA & KX389385 \\
\hline 361PtOkOk & Oku/Okinawa & 9 & P. tuberculosa & Jun 25.12 & MM & $99.5 \% \mathrm{EtOH}$ & NA & NA & NA & KX389386 \\
\hline 371PtZaAm & Ama/Zamami & 10 & P. tuberculosa & Jul 16. 12 & $\mathrm{YM}^{*_{3}}$ & $99.5 \% \mathrm{EtOH}$ & NA & KX389341 & NA & KX389387 \\
\hline 3PyOkOd & Odo/Okinawa & 1 & $P$. sp. yoron & Aug 18. 09 & MM & $99.5 \% \mathrm{EtOH}$ & KX389439 & KX389342 & KX389460 & KX389388 \\
\hline
\end{tabular}




\begin{tabular}{|c|c|c|c|c|c|c|c|c|c|c|}
\hline 14PyOkOd & Odo/Okinawa & 1 & $P$. sp. yoron & Aug 23. 09 & MM & $99.5 \% \mathrm{EtOH}$ & KX389440 & KX389343 & KX389472 & KX389389 \\
\hline 15PyOkOd & Odo/Okinawa & 1 & $P$. sp. yoron & Sep 05.09 & MM & $99.5 \% \mathrm{EtOH}$ & KX389441 & KX389344 & KX389461 & KX389390 \\
\hline 16PyOkOd & Odo/Okinawa & 1 & $P$. sp. yoron & Sep 05.09 & MM & $99.5 \% \mathrm{EtOH}$ & NA & KX389345 & KX389462 & KX389391 \\
\hline 43PyYoUk & Ukachi/Yoron & 3 & $P$. sp. yoron & Mar 04. 10 & MM & $99.5 \% \mathrm{EtOH}$ & KX389442 & KX389346 & KX389470 & KX389392 \\
\hline 44PyYoUk & Ukachi/Yoron & 3 & $P$. sp. yoron & Mar 04. 10 & MM & $99.5 \% \mathrm{EtOH}$ & NA & KX389347 & KX389471 & KX389393 \\
\hline 51PyYoUk & Ukachi(West)/Yoron & 4 & $P$. sp. yoron & Mar 04. 10 & MM & $99.5 \% \mathrm{EtOH}$ & KX389443 & KX389348 & KX389466 & KX389394 \\
\hline 53PyYoUk & Ukachi(West)/Yoron & 4 & $P . \mathrm{sp}$. yoron & Mar 04. 10 & MM & $99.5 \% \mathrm{EtOH}$ & NA & KX389349 & NA & KX389395 \\
\hline 81PyErYa & Yakomo/Okinoerabu & 5 & $P . \mathrm{sp}$. yoron & Mar 05. 10 & MM & $99.5 \% \mathrm{EtOH}$ & KX389444 & KX389350 & KX389463 & KX389396 \\
\hline 83PyErYa & Yakomo/Okinoerabu & 5 & $P$. sp. yoron & Mar 05. 10 & MM & $99.5 \% \mathrm{EtOH}$ & NA & KX389351 & KX389464 & KX389397 \\
\hline 85PyErYa & Yakomo/Okinoerabu & 5 & $P$. sp. yoron & Mar 05. 10 & MM & $99.5 \% \mathrm{EtOH}$ & KX389445 & KX389352 & KX389465 & KX389398 \\
\hline 87PyErYa & Yakomo/Okinoerabu & 5 & $P$. sp. yoron & Mar 05. 10 & MM & $99.5 \% \mathrm{EtOH}$ & NA & KX389353 & NA & KX389399 \\
\hline 105РyТoКа & Kaminomine/Tokunoshima & 7 & $P$. sp. yoron & Mar 09. 10 & MM & $99.5 \% \mathrm{EtOH}$ & KX389446 & KX389354 & KX389467 & KX389400 \\
\hline 107РyТoKa & Kaminomine/Tokunoshima & 7 & $P$. sp. yoron & Mar 09. 10 & MM & $99.5 \% \mathrm{EtOH}$ & KX389447 & KX389355 & KX389468 & KX389401 \\
\hline 109РуТоКа & Kaminomine/Tokunoshima & 7 & $P$. sp. yoron & Mar 09. 10 & MM & $99.5 \% \mathrm{EtOH}$ & NA & KX389356 & KX389469 & NA \\
\hline 359PyOkAk & Akazaki/Okinawa & 8 & $P$. sp. yoron & Jun 24. 12 & MM & $99.5 \% \mathrm{EtOH}$ & KX389448 & KX389357 & NA & KX389402 \\
\hline 42PmYoUk & Ukachi/Yoron & 3 & P. mutuki & Mar 04. 10 & MM & $99.5 \% \mathrm{EtOH}$ & NA & KX389366 & KX389488 & KX389403 \\
\hline 61PmYoUk & Ukachi/Yoron & 3 & P. mutuki & Mar 04. 10 & JDR & $99.5 \% \mathrm{EtOH}$ & NA & NA & NA & KX389404 \\
\hline 73PmErYa & Yakomo/Okinoerabu & 5 & P. mutuki & Mar 05. 10 & MM & $99.5 \% \mathrm{EtOH}$ & NA & NA & KX389484 & KX389405 \\
\hline 75PmErYa & Yakomo/Okinoerabu & 5 & P. mutuki & Mar 05. 10 & MM & $99.5 \% \mathrm{EtOH}$ & NA & KX389367 & KX389482 & KX389406 \\
\hline 77PmErYa & Yakomo/Okinoerabu & 5 & P. mutuki & Mar 05. 10 & MM & $99.5 \% \mathrm{EtOH}$ & NA & NA & KX389481 & KX389407 \\
\hline 93РmТoYo & Yonama/Tokunoshima & 6 & P. mutuki & Mar 08.10 & MM & $99.5 \% \mathrm{EtOH}$ & NA & NA & NA & KX389408 \\
\hline
\end{tabular}




\begin{tabular}{|c|c|c|c|c|c|c|c|c|c|c|}
\hline 94PmToYo & Yonama/Tokunoshima & 6 & P. mutuki & Mar 08. 10 & MM & $99.5 \% \mathrm{EtOH}$ & NA & NA & NA & KX389409 \\
\hline 95PmToYo & Yonama/Tokunoshima & 6 & P. mutuki & Mar 08. 10 & MM & $99.5 \% \mathrm{EtOH}$ & NA & KX389368 & KX389487 & NA \\
\hline 216PmOkOd & Odo/Okinawa & 1 & P. mutuki & May 04.11 & MM & $99.5 \%$ EtOH & NA & KX389369 & NA & KX389410 \\
\hline 218PmOkOd & Odo/Okinawa & 1 & P. mutuki & May 04.11 & MM & $99.5 \% \mathrm{EtOH}$ & NA & NA & KX389483 & KX389411 \\
\hline 220PmOkOd & Odo/Okinawa & 1 & P. mutuki & May 04.11 & MM & $99.5 \%$ EtOH & NA & NA & KX389489 & KX389412 \\
\hline 222PmOkOd & Odo/Okinawa & 1 & P. mutuki & May 04.11 & MM & $99.5 \%$ EtOH & NA & NA & KX389485 & KX389413 \\
\hline $240 \mathrm{PmErSu}$ & Sumiyoshi/Okinoerabu & 11 & P. mutuki & Jun 18.11 & MM & $99.5 \% \mathrm{EtOH}$ & NA & NA & NA & KX389414 \\
\hline 280PmToKa & Kaminomine/Tokunoshima & 7 & P. mutuki & Oct 05.11 & MM & $99.5 \% \mathrm{EtOH}$ & NA & NA & NA & KX389415 \\
\hline 316PmOkKo & Komesu/Okinawa & 12 & P. mutuki? & Feb 25.12 & MM & $99.5 \%$ EtOH & NA & KX389370 & KX389480 & KX389416 \\
\hline 319PmOkMi & Mizugama/Okinawa & 13 & P. mutuki? & Mar 29. 12 & MM & $99.5 \% \mathrm{EtOH}$ & NA & KX389371 & KX389486 & KX389417 \\
\hline 320PmOkMi & Mizugama/Okinawa & 13 & P. mutuki & Mar 29. 12 & MM & $99.5 \% \mathrm{EtOH}$ & NA & NA & NA & KX389418 \\
\hline 323PmOkTe & Teniya/Okinawa & 14 & P. mutuki & Apr 05.12 & MM & $99.5 \% \mathrm{EtOH}$ & NA & NA & NA & KX389419 \\
\hline 324PmOkTe & Teniya/Okinawa & 14 & P. mutuki & Apr 05.12 & MM & $99.5 \% \mathrm{EtOH}$ & NA & NA & NA & KX389420 \\
\hline 349PmOkSh & Shioya Bay/Okinawa & 15 & P. mutuki & Jun 17.12 & MM & $99.5 \% \mathrm{EtOH}$ & NA & NA & NA & KX389421 \\
\hline 362PmOkOk & Oku/Okinawa & 9 & P. mutuki & Jun 25.12 & MM & $99.5 \% \mathrm{EtOH}$ & NA & NA & NA & KX389422 \\
\hline 155PamErYa & Yakomo/Okinoerabu & 5 & $P$. aff. mutuki & July 25.10 & MM & $70 \% \mathrm{EtOH}$ & KX389449 & KX389358 & KX389473 & KX389423 \\
\hline 159PamToKa & Kaminomine/Tokunoshima & 7 & P. aff. mutuki & July 28.10 & MM & $70 \% \mathrm{EtOH}$ & NA & NA & NA & KX389424 \\
\hline 229PamErYa & Yakomo/Okinoerabu & 5 & $P$. aff. mutuki & Jun 17.11 & MM & $99.5 \% \mathrm{EtOH}$ & KX389450 & KX389359 & KX389474 & NA \\
\hline 231PamErYa & Yakomo/Okinoerabu & 5 & P. aff. mutuki & Jun 17.11 & MM & $99.5 \% \mathrm{EtOH}$ & KX389451 & KX389360 & KX389475 & KX389425 \\
\hline 233PamErYa & Yakomo/Okinoerabu & 5 & P. aff. mutuki & Jun 17. 11 & MM & $99.5 \% \mathrm{EtOH}$ & KX389452 & KX389361 & KX389476 & KX389426 \\
\hline 237PamErSu & Sumiyoshi/Okinoerabu & 11 & $P$. aff. mutuki & Jun 18.11 & MM & $99.5 \% \mathrm{EtOH}$ & KX389453 & KX389362 & KX389479 & NA \\
\hline
\end{tabular}




\begin{tabular}{|c|c|c|c|c|c|c|c|c|c|c|}
\hline 248PamToKa & Kaminomine/Tokunoshima & 7 & $P$. aff. mutuki & Jun 21.11 & MM & $99.5 \% \mathrm{EtOH}$ & KX389454 & KX389363 & KX389478 & KX389427 \\
\hline 250PamToKa & Kaminomine/Tokunoshima & 7 & $P$. aff. mutuki & Jun 21.11 & MM & $99.5 \% \mathrm{EtOH}$ & KX389455 & KX389364 & KX389477 & KX389428 \\
\hline 328PamOkTe & Teniya/Okinawa & 14 & $P$. aff. mutuki & Apr 05.12 & MM & $99.5 \% \mathrm{EtOH}$ & KX389456 & NA & NA & KX389429 \\
\hline 364PamOkOk & Oku/Okinawa & 9 & $P$. aff. mutuki & Jun 25.12 & MM & $99.5 \% \mathrm{EtOH}$ & KX389457 & KX389365 & NA & KX389430 \\
\hline 215PsOkIk & Ikei E/Okinawa & 16 & $\begin{array}{l}\text { Palythoa sp. } \\
\text { sakurajimensis }\end{array}$ & Apr 29. 11 & MM & $99.5 \% \mathrm{EtOH}$ & NA & KX389372 & KX389491 & KX389431 \\
\hline $1595 \#$ & Wanli Tung/Taiwan & 2 & $\begin{array}{l}\text { Palythoa sp. } \\
\text { sakurajimensis }\end{array}$ & Sep. 09 & JDR & $99.5 \% \mathrm{EtOH}$ & KF499697 & KF499661 & KX389490 & KX389432 \\
\hline $1597 \#$ & Wanli Tung/Taiwan & 1 & $\begin{array}{l}\text { Palythoa sp. } \\
\text { sakurajimensis }\end{array}$ & Sep. 09 & JDR & $99.5 \% \mathrm{EtOH}$ & KF499696 & KF499662 & KF499778 & KX389433 \\
\hline $1635 \#$ & Bitouchiao/Taiwan & 8 & $\begin{array}{l}\text { Palythoa sp. } \\
\text { sakurajimensis }\end{array}$ & Sep. 09 & JDR & $99.5 \% \mathrm{EtOH}$ & KF499735 & KF499652 & KF499783 & KX389434 \\
\hline 321PhOkMi & Mizugama/Okinawa & 13 & P. heliodiscus & Mar 29. 12 & MM & $99.5 \% \mathrm{EtOH}$ & KX389458 & NA & NA & KX389435 \\
\hline TN116 & Mizugama/Okinawa & 13 & P. heliodiscus & Aug 19. 10 & $\mathrm{TN}_{4}$ & $99.5 \% \mathrm{EtOH}$ & NA & NA & NA & KX389436 \\
\hline TN119 & Mizugama/Okinawa & 13 & P. heliodiscus & Jul 4. 12 & $\mathrm{TN}$ & $99.5 \% \mathrm{EtOH}$ & NA & NA & NA & KX389437 \\
\hline TN121 & Mizugama/Okinawa & 13 & P. heliodiscus & Jul 4. 12 & $\mathrm{TN}$ & $99.5 \% \mathrm{EtOH}$ & NA & NA & NA & KX389438 \\
\hline
\end{tabular}

MM*1: Masaru Mizuyama, JDR*2: James Davis Reimer, YM*3: Yu Miyazaki, TN*4: Tohru Nishimura

GPS code: 1, N $26^{\circ} 05^{\prime} 15^{\prime \prime}$, E $127^{\circ} 42^{\prime} 30^{\prime \prime} ; \mathbf{2}$, N $27^{\circ} 01^{\prime} 16^{\prime \prime}$, E $128^{\circ} 26^{\prime} 28^{\prime \prime} ; \mathbf{3}, \mathrm{N} 27^{\circ} 04^{\prime} 00^{\prime \prime}$, E $128^{\circ} 25^{\prime} 24^{\prime \prime}$,

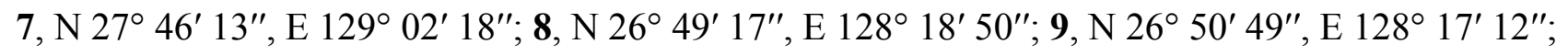


10, N $26^{\circ} 13^{\prime} 35^{\prime \prime}$, E $127^{\circ} 17^{\prime} 33^{\prime \prime} ;$ 11, N $27^{\circ} 21^{\prime} 21^{\prime \prime}$, E $128^{\circ} 31^{\prime} 44^{\prime \prime} ;$ 12, N $26^{\circ} 05^{\prime} 17^{\prime \prime}$, E $127^{\circ} 42^{\prime} 06^{\prime \prime}$;

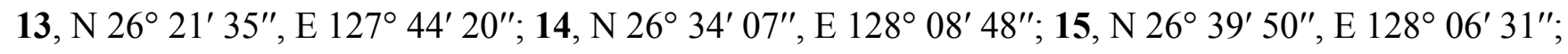

16, $\mathrm{N} 26^{\circ} 23^{\prime} 40^{\prime \prime}, \mathrm{E} 128^{\circ} 00^{\prime} 22^{\prime \prime}$. 


\section{Table 3(on next page)}

The mean number of tentacles \pm standard deviation and results of Mann-Whitney $\mathrm{U}$ test with Bonferroni correction between each Palythoa species pairs. $\mathrm{N}=$ total number of examined polyps for each species (one per colony). 
1 Table 3. The mean number of tentacles \pm standard deviation and results of Mann-Whitney

$2 \mathrm{U}$ test with Bonferroni correction between each Palythoa species pairs. $\mathrm{N}=$ total number

3 of examined polyps for each species (one per colony).

4

\begin{tabular}{|c|c|c|c|c|}
\hline Species & P. tuberculosa & $P . \mathrm{sp}$. yoron & P. mutuki & $P$. aff. mutuki \\
\hline & & \multicolumn{3}{|c|}{ Mann-Whitney U test } \\
\hline P. tuberculosa & $\begin{array}{c}31.6 \pm 3.4 \\
(\mathrm{~N}=11)\end{array}$ & $<0.001$ & $<0.001$ & $<0.001$ \\
\hline$P$. sp. yoron & & $\begin{array}{c}40.5 \pm 2.56 \\
(\mathrm{~N}=8)\end{array}$ & $<0.001$ & $<0.001$ \\
\hline P. mutuki & & & $\begin{array}{c}54.4 \pm 7.43 \\
(\mathrm{~N}=7)\end{array}$ & $<0.001$ \\
\hline$P$. aff. mutuki & & & & $\begin{array}{c}71 \pm 4.14 \\
(\mathrm{~N}=8)\end{array}$ \\
\hline
\end{tabular}

5

6 


\section{Table 4 (on next page)}

Cnidae types and sizes of Palythoa aff. mutuki, Palythoa mutuki, Palythoa sp. yoron and Palythoa tuberculosa.

Frequency: relative abundance of cnidae type in decreasing order; numerous, common, occasional, rare, very rare ( $\mathrm{N}=$ number of specimens found/total specimens examined). 
1 Table 4. Cnidae types and sizes of Palythoa aff. mutuki, Palythoa mutuki, Palythoa sp. yoron and Palythoa tuberculosa. Frequency:

2 relative abundance of cnidae type in decreasing order; numerous, common, occasional, rare, very rare $(\mathrm{N}=$ number of specimens

3 found/total specimens examined).

\begin{tabular}{|c|c|c|c|c|c|c|c|c|}
\hline & \multicolumn{2}{|c|}{ Palythoa aff. mutuki } & \multicolumn{2}{|c|}{ Palythoa mutuki } & \multicolumn{2}{|c|}{ Palythoa sp. yoron } & \multicolumn{2}{|c|}{ Palythoa tuberculosa } \\
\hline & $\begin{array}{c}\text { Length } x \\
\text { width }(\mu \mathrm{m})\end{array}$ & Frequency & $\begin{array}{c}\text { Length } x \\
\text { width }(\mu \mathrm{m})\end{array}$ & Frequency & $\begin{array}{c}\text { Length } \mathrm{x} \\
\text { width }(\mu \mathrm{m})\end{array}$ & Frequency & $\begin{array}{c}\text { Length } x \\
\text { width }(\mu \mathrm{m})\end{array}$ & Frequency \\
\hline Tentacles & $\square$ & $\square$ & $\square$ & $\square$ & $\square$ & $\square$ & $\square$ & $\square$ \\
\hline Spirocysts & $12-36 \times 3-8$ & $\begin{array}{c}\text { Numerous } \\
(3 / 3)\end{array}$ & $13-41 \times 2-8$ & $\begin{array}{c}\text { Numerous } \\
(3 / 3)\end{array}$ & $11-36 \times 2-6$ & $\begin{array}{c}\text { Common } \\
(3 / 3)\end{array}$ & $17-37 \times 3-7$ & $\begin{array}{c}\text { Numerous } \\
(3 / 3)\end{array}$ \\
\hline Basitrichs & $16-55 \times 4-7$ & $\begin{array}{c}\text { Common } \\
(3 / 3)\end{array}$ & $14-63 \times 3-8$ & $\begin{array}{c}\text { Numerous } \\
(3 / 3)\end{array}$ & $25-73 \times 2-9$ & $\begin{array}{c}\text { Numerous } \\
(3 / 3)\end{array}$ & $25-37 \times 4-6$ & $\begin{array}{c}\text { Common } \\
(3 / 3)\end{array}$ \\
\hline Holotrichs small & $15-20 \times 5-9$ & Rare (1/3) & - & 0 & - & 0 & - & 0 \\
\hline Holotrichs large & $\begin{array}{c}35-77 \times 19- \\
31\end{array}$ & $\begin{array}{c}\text { Occasional } \\
(2 / 3)\end{array}$ & $39-78 \times 18-32$ & $\begin{array}{c}\text { Numerous } \\
(3 / 3)\end{array}$ & $\begin{array}{c}47-82 \times 21- \\
34\end{array}$ & $\begin{array}{c}\text { Numerous } \\
(3 / 3)\end{array}$ & $28-85 \times 17-37$ & $\begin{array}{c}\text { Occasional } \\
(2 / 3)\end{array}$ \\
\hline P-mastigophores & $\begin{array}{c}25-50 \times 5- \\
10\end{array}$ & $\begin{array}{c}\text { Common } \\
(3 / 3)\end{array}$ & $15 \times 4$ & $\begin{array}{l}\text { Very rare } \\
\text { (single } \\
\text { specimen) }\end{array}$ & $26-29 \times 5-6$ & $\begin{array}{c}\text { Occasional } \\
\text { (2/3) }\end{array}$ & $46-51 \times 6-8$ & Rare $(1 / 3)$ \\
\hline Column & $\square$ & $\square$ & $\square$ & $\square$ & $\square$ & $\square$ & $\square$ & $\square$ \\
\hline Spirocysts & - & 0 & - & 0 & - & 0 & $16-34 \times 3-6$ & Rare $(1 / 3)$ \\
\hline Basitrichs & $21-53 \times 5-7$ & $\begin{array}{c}\text { Occasional } \\
\qquad(2 / 3)\end{array}$ & $25-83 \times 5-9$ & $\begin{array}{c}\text { Common } \\
(3 / 3)\end{array}$ & - & 0 & $25-69 \times 4-10$ & $\begin{array}{c}\text { Common } \\
(3 / 3)\end{array}$ \\
\hline Holotrichs small & $21 \times 7$ & $\begin{array}{c}\text { Very rare } \\
\text { (single }\end{array}$ & $19-24 \times 8$ & Rare (1/3) & - & 0 & - & 0 \\
\hline
\end{tabular}


specimen)

\begin{tabular}{|c|c|c|c|c|c|c|c|c|}
\hline Holotrichs large & $\begin{array}{c}32-69 \times 15- \\
30\end{array}$ & $\begin{array}{c}\text { Numerous } \\
(3 / 3)\end{array}$ & $24-85 \times 17-31$ & $\begin{array}{c}\text { Numerous } \\
(3 / 3)\end{array}$ & $\begin{array}{c}39-88 \times 18- \\
36\end{array}$ & $\begin{array}{c}\text { Numerous } \\
(3 / 3)\end{array}$ & $34-81 \times 14-38$ & $\begin{array}{c}\text { Numerous } \\
(3 / 3)\end{array}$ \\
\hline P-mastigophores & $21-46 \times 6-8$ & Rare (1/3) & - & 0 & - & 0 & $52-54 \times 7-8$ & $\begin{array}{c}\text { Occasional } \\
(2 / 3)\end{array}$ \\
\hline Actinopharynx & $\square$ & $\square$ & $\square$ & $\square$ & $\square$ & $\square$ & $\square$ & $\square$ \\
\hline Spirocysts & - & 0 & $18-32 \times 4-6$ & $\begin{array}{c}\text { Occasional } \\
\qquad(2 / 3)\end{array}$ & $16-65 \times 3-8$ & $\begin{array}{l}\text { Occasional } \\
\qquad(2 / 3)\end{array}$ & $19-36 \times 4-7$ & Rare $(1 / 3)$ \\
\hline Basitrichs & $\begin{array}{c}19-55 \times 4- \\
10\end{array}$ & $\begin{array}{c}\text { Numerous } \\
(3 / 3)\end{array}$ & $16-72 \times 3-8$ & $\begin{array}{c}\text { Numerous } \\
\qquad(3 / 3)\end{array}$ & $17-69 \times 3-9$ & $\begin{array}{c}\text { Numerous } \\
(3 / 3)\end{array}$ & $22-62 \times 3-10$ & $\begin{array}{c}\text { Numerous } \\
(3 / 3)\end{array}$ \\
\hline Holotrichs small & $19-20 \times 7-8$ & Rare (1/3) & - & 0 & - & 0 & - & 0 \\
\hline Holotrichs large & $\begin{array}{c}34-93 \times 18- \\
33\end{array}$ & $\begin{array}{c}\text { Numerous } \\
(3 / 3)\end{array}$ & $34-72 \times 4-31$ & $\begin{array}{c}\text { Numerous } \\
(3 / 3)\end{array}$ & $\begin{array}{c}38-77 \times 10- \\
33\end{array}$ & $\begin{array}{c}\text { Common } \\
(3 / 3)\end{array}$ & $40-85 \times 18-38$ & $\begin{array}{c}\text { Numerous } \\
(3 / 3)\end{array}$ \\
\hline P-mastigophores & $\begin{array}{c}29-40 \times 7- \\
11\end{array}$ & Rare (1/3) & - & 0 & $21-29 \times 6-7$ & $\begin{array}{c}\text { Occasional } \\
\qquad(2 / 3)\end{array}$ & $28-52 \times 5-8$ & Rare (1/3) \\
\hline $\begin{array}{c}\text { Mesenteries } \\
\text { filaments }\end{array}$ & $\square$ & $\square$ & $\square$ & $\square$ & $\square$ & $\square$ & $\square$ & $\square$ \\
\hline Spirocysts & $15 \times 24$ & $\begin{array}{c}\text { Very rare } \\
\text { (single } \\
\text { specimen) }\end{array}$ & - & 0 & - & 0 & $28 \times 8$ & $\begin{array}{c}\text { Very rare } \\
\text { (single } \\
\text { specimen) }\end{array}$ \\
\hline Basitrichs & $\begin{array}{c}25-69 \times 4- \\
10\end{array}$ & $\begin{array}{c}\text { Numerous } \\
\qquad(3 / 3)\end{array}$ & $41-80 \times 5-10$ & $\begin{array}{c}\text { Numerous } \\
\qquad(3 / 3)\end{array}$ & $33-66 \times 4-9$ & $\begin{array}{c}\text { Numerous } \\
(3 / 3)\end{array}$ & $24-74 \times 5-9$ & $\begin{array}{c}\text { Numerous } \\
(3 / 3)\end{array}$ \\
\hline Holotrichs small & - & 0 & - & 0 & - & 0 & - & 0 \\
\hline
\end{tabular}




\begin{tabular}{|c|c|c|c|c|c|c|c|c|}
\hline Holotrichs large & $\begin{array}{c}37-64 \times 22- \\
35\end{array}$ & $\begin{array}{c}\text { Numerous } \\
\qquad(3 / 3)\end{array}$ & $44-83 \times 21-32$ & $\begin{array}{c}\text { Numerous } \\
(3 / 3)\end{array}$ & $\begin{array}{c}51-90 \times 21- \\
35\end{array}$ & $\begin{array}{c}\text { Numerous } \\
(3 / 3)\end{array}$ & $45-85 \times 22-42$ & $\begin{array}{c}\text { Numerous } \\
(3 / 3)\end{array}$ \\
\hline P-mastigophores & $\begin{array}{c}27-39 \times 5- \\
10\end{array}$ & $\begin{array}{c}\text { Occasional } \\
2 / 3\end{array}$ & $21 \times 6$ & $\begin{array}{l}\text { Very rare } \\
\text { (single } \\
\text { specimen) }\end{array}$ & $21-29 \times 4-8$ & $\begin{array}{c}\text { Common } \\
(3 / 3)\end{array}$ & $21-57 \times 5-11$ & $\begin{array}{c}\text { Occasional } \\
(2 / 3)\end{array}$ \\
\hline
\end{tabular}

4 


\section{Table 5 (on next page)}

GenBank accession numbers of genus Palythoa sequences used in this study. 
1 Table 5. GenBank accession numbers of genus Palythoa sequences used in this study. 2

\begin{tabular}{|c|c|c|c|c|c|}
\hline $\begin{array}{l}\text { Sequence } \\
\text { code }\end{array}$ & Species & $\begin{array}{c}\text { mtCOI } \\
\text { accession } \\
\text { number }\end{array}$ & $\begin{array}{l}\text { mt 16S-rDNA } \\
\text { accession number }\end{array}$ & $\begin{array}{c}\text { ITS-rDNA } \\
\text { accession number }\end{array}$ & Reference \\
\hline PtEW3 & P. tuberculosa & NA & NA & DQ997902 & Reimer et al. 2007a \\
\hline PtAT1 & P. tuberculosa & AB219195 & NA & NA & Reimer et al. 2006 \\
\hline PtAT2 & P. tuberculosa & AB219196 & NA & DQ997897 & Reimer et al. 2006 \\
\hline PtBA1 & P. tuberculosa & AB219197 & NA & NA & Reimer et al. 2006 \\
\hline PtWK1 & P. tuberculosa & AB219198 & NA & NA & Reimer et al. 2006 \\
\hline PtYS1 & P. tuberculosa & AB219200 & NA & NA & Reimer et al. 2006 \\
\hline PtMil1 & P. tuberculosa & AB219199 & AB219218 & NA & Reimer et al. 2006 \\
\hline PtIsK3 & P. tuberculosa & AB219203 & NA & NA & Reimer et al. 2006 \\
\hline PtEO1 & P. tuberculosa & AB219205 & NA & NA & Reimer et al. 2006 \\
\hline PtKK1 & P. tuberculosa & AB219206 & NA & NA & Reimer et al. 2006 \\
\hline PtIsK2 & P. tuberculosa & AB219207 & NA & NA & Reimer et al. 2006 \\
\hline PtYS4 & P. tuberculosa & NA & NA & DQ997903 & Reimer et al. 2006 \\
\hline PtIrHo16 & P. tuberculosa & NA & NA & DQ997909 & Reimer et al. 2006 \\
\hline PtCN1 & P. tuberculosa & NA & NA & DQ997896 & Reimer et al. 2006 \\
\hline PtCN14 & P. tuberculosa & NA & NA & DQ997933 & Reimer et al. 2006 \\
\hline PtIsO1 & P. tuberculosa & AB219202 & NA & NA & Reimer et al. 2006 \\
\hline PtIsO13 & P. tuberculosa & NA & NA & DQ997919 & Reimer et al. 2006 \\
\hline PtIsO11 & P. tuberculosa & NA & NA & DQ997929 & Reimer et al. 2006 \\
\hline PtIsrael13 & P. tuberculosa & NA & NA & DQ997931 & Reimer et al. 2006 \\
\hline PtOtsFu11 & P. tuberculosa & NA & NA & DQ997945 & Reimer et al. $2007 \mathrm{a}$ \\
\hline PtIrHo11 & P. tuberculosa & NA & NA & DQ997914 & Reimer et al. $2007 \mathrm{a}$ \\
\hline PtOtsNi3 & P. tuberculosa & NA & NA & DQ997939 & Reimer et al. 2006 \\
\hline PtIrHo13 & P. tuberculosa & NA & NA & DQ997911 & Reimer et al. $2007 \mathrm{a}$ \\
\hline PtL1 & P. tuberculosa & NA & EU333661 & NA & Reimer \& Todd 2009 \\
\hline
\end{tabular}




\begin{tabular}{|c|c|c|c|c|c|}
\hline PtK2 & P. tuberculosa & NA & EU333654 & NA & Reimer \& Todd 2009 \\
\hline PtL3 & P. tuberculosa & NA & EU333662 & NA & Reimer \& Todd 2009 \\
\hline PtK7 & P. tuberculosa & NA & EU333657 & NA & Reimer \& Todd 2009 \\
\hline PtYoS1 & $P$. sp. yoron & AB219204 & AB219219 & DQ997921 & Reimer et al. 2007a \\
\hline PmAT & P. mutuki & AB219209 & NA & NA & Reimer et al. 2006 \\
\hline PmPM2 & P. mutuki & AB219210 & NA & NA & Reimer et al. 2006 \\
\hline Pm1162 & P. mutuki & JF419796 & NA & NA & Reimer et al. 2011 \\
\hline Pm1163 & P. mutuki & JF419788 & NA & NA & Reimer et al. 2011 \\
\hline PmBA1 & P. mutuki & AB219215 & NA & NA & Reimer et al. 2006 \\
\hline PmYS1 & P. mutuki & AB219213 & NA & NA & Reimer et al. 2006 \\
\hline PmIrHo1 & P. mutuki & NA & NA & DQ997888 & Reimer et al. 2007a \\
\hline PmYS2 & P. mutuki & NA & NA & DQ997892 & Reimer et al. 2007a \\
\hline PpAT1 & P. mutuki & AB219211 & AB219220 & DQ997891 & Reimer et al. 2007a \\
\hline PmMil1 & P. mutuki & AB219217 & AB219225 & DQ997889 & Reimer et al. $2007 \mathrm{a}$ \\
\hline PmEs1 & P. mutuki & NA & NA & DQ997894 & Reimer et al. $2007 \mathrm{a}$ \\
\hline PpAT2 & P. mutuki & AB219212 & AB219221 & NA & Reimer et al. 2006 \\
\hline PpYS1 & P. mutuki & NA & AB219222 & NA & Reimer et al. 2006 \\
\hline PamTOB51 & $P$. aff. mutuki & NA & GQ464873 & GQ464902 & Swain 2010 \\
\hline PsPSH1 & $P$. sp. sakurajimensis & NA & DQ997842 & DQ997886 & Reimer et al. 2007a \\
\hline PsPWS1 & $P$. sp. sakurajimensis & NA & DQ997863 & DQ997887 & Reimer et al. $2007 \mathrm{a}$ \\
\hline PsPEWn1 & $P$. sp. sakurajimensis & NA & DQ997862 & NA & Reimer et al. 2007a \\
\hline PsGYi & $P$. sp. sakurajimensis & KF499720 & NA & NA & Reimer et al. 2013 \\
\hline
\end{tabular}




\begin{tabular}{cccccc} 
Ps1597 & P. sp. sakurajimensis & KF499696 & NA & KF499778 & Reimer et al. 2013 \\
Ps1635 & P. sp. sakurajimensis & KF499735 & NA & KF499776 & Reimer et al. 2013 \\
PhIsK2 & P. heliodiscus & NA & NA & DQ997885 & Reimer et al. 2007a \\
PhIsK11 & P. heliodiscus & NA & NA & DQ997880 & Reimer et al. 2007a \\
PhEK1 & P. heliodiscus & NA & NA & DQ997882 & Reimer et al. 2007a \\
PhSaiLL1 & P. heliodiscus & AB219214 & AB219223 & NA & Reimer et al. 2006 \\
PhEK1 & P. heliodiscus & NA & AB219224 & NA & Reimer et al. 2006 \\
PhPpM1 & P. heliodiscus & AB219216 & NA & NA & Reimer et al. 2006 \\
\hline
\end{tabular}

3 


\section{Table 6(on next page)}

Ovary development in polyps of four species of Palythoa.

Number of polyps possessing developing and/or developed ovaries (N), total number of examined polyps (Nt) and ratio of $\mathrm{N}$ to $\mathrm{Nt}$ for collected specimens of $P$. tuberculosa, $P$. mutuki, P. sp. yoron and P. aff. mutuki on each sampling date. * indicates observation of developed ovaries in specimens. 
1 Table 6. Number of polyps possessing developing and/or developed ovaries $(\mathrm{N})$, total number

2 of examined polyps $(\mathrm{Nt})$ and ratio of $\mathrm{N}$ to $\mathrm{Nt}$ for collected specimens of $P$. tuberculosa, $P$.

3 mutuki, $P$. sp. yoron and $P$. aff. mutuki on each sampling date. * indicates observation of

4 developed ovaries in specimens.

\begin{tabular}{|c|c|c|c|c|c|c|c|c|c|c|c|c|}
\hline \multirow{2}{*}{$\begin{array}{c}\text { Species } \\
\text { Date }\end{array}$} & \multicolumn{3}{|c|}{ P. tuberculosa } & \multicolumn{3}{|c|}{ P. mutuki } & \multicolumn{3}{|c|}{$P$. sp. yoron } & \multicolumn{3}{|c|}{$P$. aff. mutuki } \\
\hline & $\mathrm{N}$ & $\mathrm{Nt}$ & $\begin{array}{c}\mathrm{N} / \mathrm{Nt} \\
(\%)\end{array}$ & $\mathrm{N}$ & $\mathrm{Nt}$ & $\begin{array}{c}\mathrm{N} / \mathrm{Nt} \\
(\%)\end{array}$ & $\mathrm{N}$ & $\mathrm{Nt}$ & $\begin{array}{c}\mathrm{N} / \mathrm{Nt} \\
(\%)\end{array}$ & $\mathrm{N}$ & $\mathrm{Nt}$ & $\begin{array}{c}\mathrm{N} / \mathrm{Nt} \\
(\%)\end{array}$ \\
\hline 2010.06 .15 & 2 & 60 & 3 & 0 & 13 & 0 & 0 & 18 & 0 & - & - & - \\
\hline 07.28 & 36 & 61 & $* 59$ & 12 & 22 & 55 & 0 & 49 & 0 & - & - & - \\
\hline 08.30 & 42 & 80 & 53 & 5 & 20 & 25 & 0 & 52 & 0 & - & - & - \\
\hline 09.20 & 27 & 118 & $* 23$ & 7 & 25 & 28 & 0 & 51 & 0 & - & - & - \\
\hline 10.26 & 0 & 198 & 0 & NA & NA & NA & 16 & 52 & $* 31$ & - & - & - \\
\hline 12.08 & 0 & 89 & 0 & 0 & 54 & 0 & 0 & 53 & 0 & - & - & - \\
\hline 2011.06 .21 & 40 & 78 & 51 & 1 & 36 & 3 & 0 & 54 & 0 & 4 & 4 & $* 100$ \\
\hline 07.23 & 9 & 63 & 14 & 14 & 30 & 47 & 0 & 53 & 0 & 4 & 5 & 80 \\
\hline 08.22 & 10 & 63 & 16 & 14 & 40 & 35 & 1 & 43 & 2 & 1 & 7 & 14 \\
\hline 10.05 & 10 & 65 & 15 & 15 & 37 & 41 & 18 & 46 & $* 41$ & 0 & 6 & 0 \\
\hline 11.09 & 0 & 72 & 0 & 2 & 34 & 6 & 15 & 40 & $* 40$ & 0 & 6 & 0 \\
\hline 11.28 & 5 & 52 & 10 & 0 & 31 & 0 & 0 & 44 & 0 & NA & NA & NA \\
\hline 12.16 & 0 & 63 & 0 & 0 & 36 & 0 & 0 & 40 & 0 & 0 & 9 & 0 \\
\hline 2012.02 .12 & 0 & 82 & 0 & 0 & 52 & 0 & 0 & 47 & 0 & 0 & 8 & 0 \\
\hline
\end{tabular}

5

6 


\section{Figure 1}

Map of Palythoa species specimen locations in the Ryukyu Archipelago in this study.

Map of Palythoa species specimen locations in the Ryukyu Archipelago, including Okinawajima I., Zamami-jima I., Yoron-to I., Okinoerabu-jima I., and Tokunoshima I. Locations for specimens collected in this study represented by closed symbols, location for spawning timing investigations represented by open symbol. 


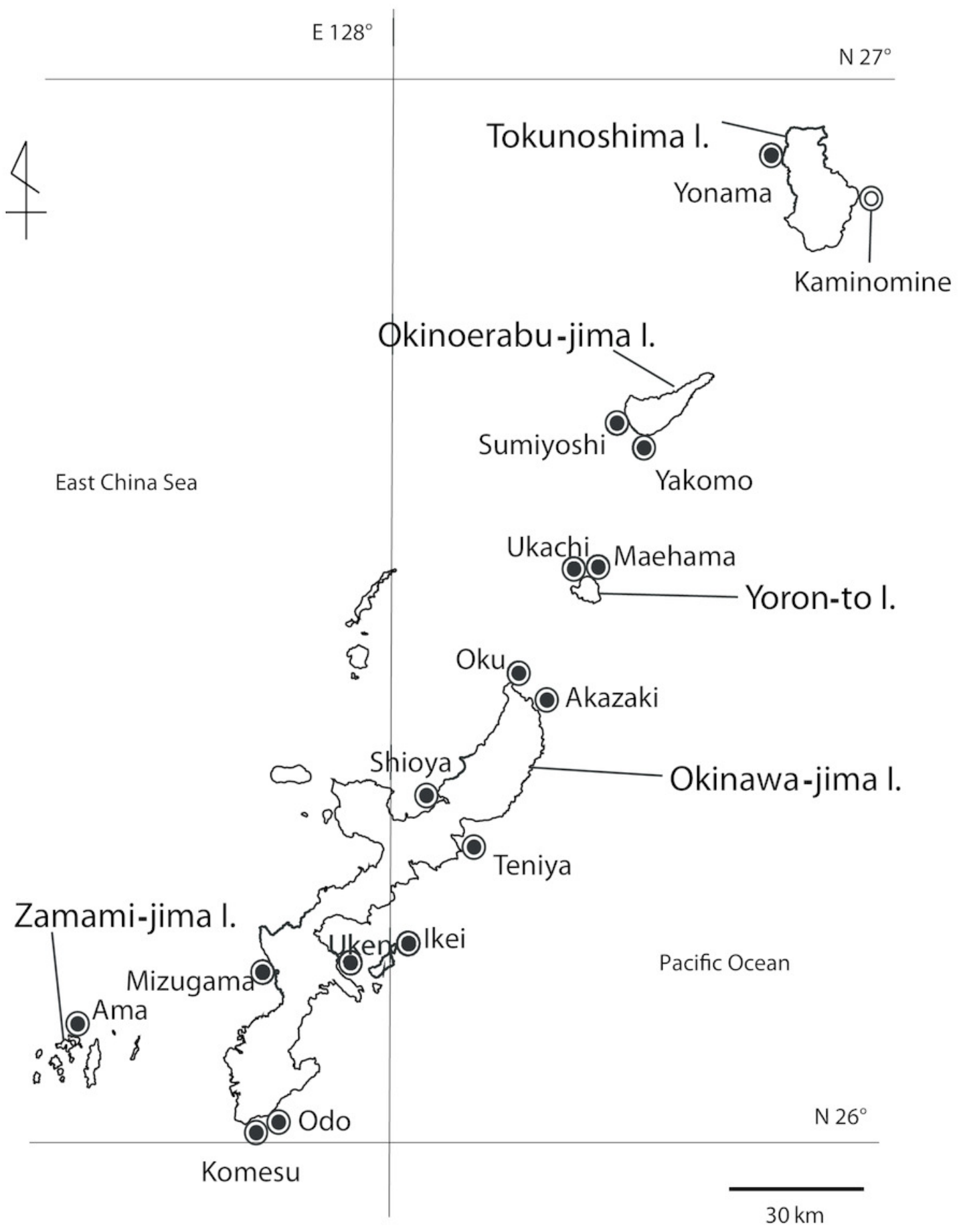


Figure 2

In situ images of Palythoa species examined in this study.

In situ images of A Palythoa tuberculosa, B P. mutuki, C P. sp. yoron, D P. aff. mutuki, E $P$. tuberculosa (left; "Pt") and P. sp. yoron (right, "Py"), and F P. mutuki (left, "Pm") and P. aff. mutuki (right, "Pam"). Scale bars in A, C, E are $2 \mathrm{~cm}$, in B, D, F $1 \mathrm{~cm}$. All images taken by M. Mizuyama. 


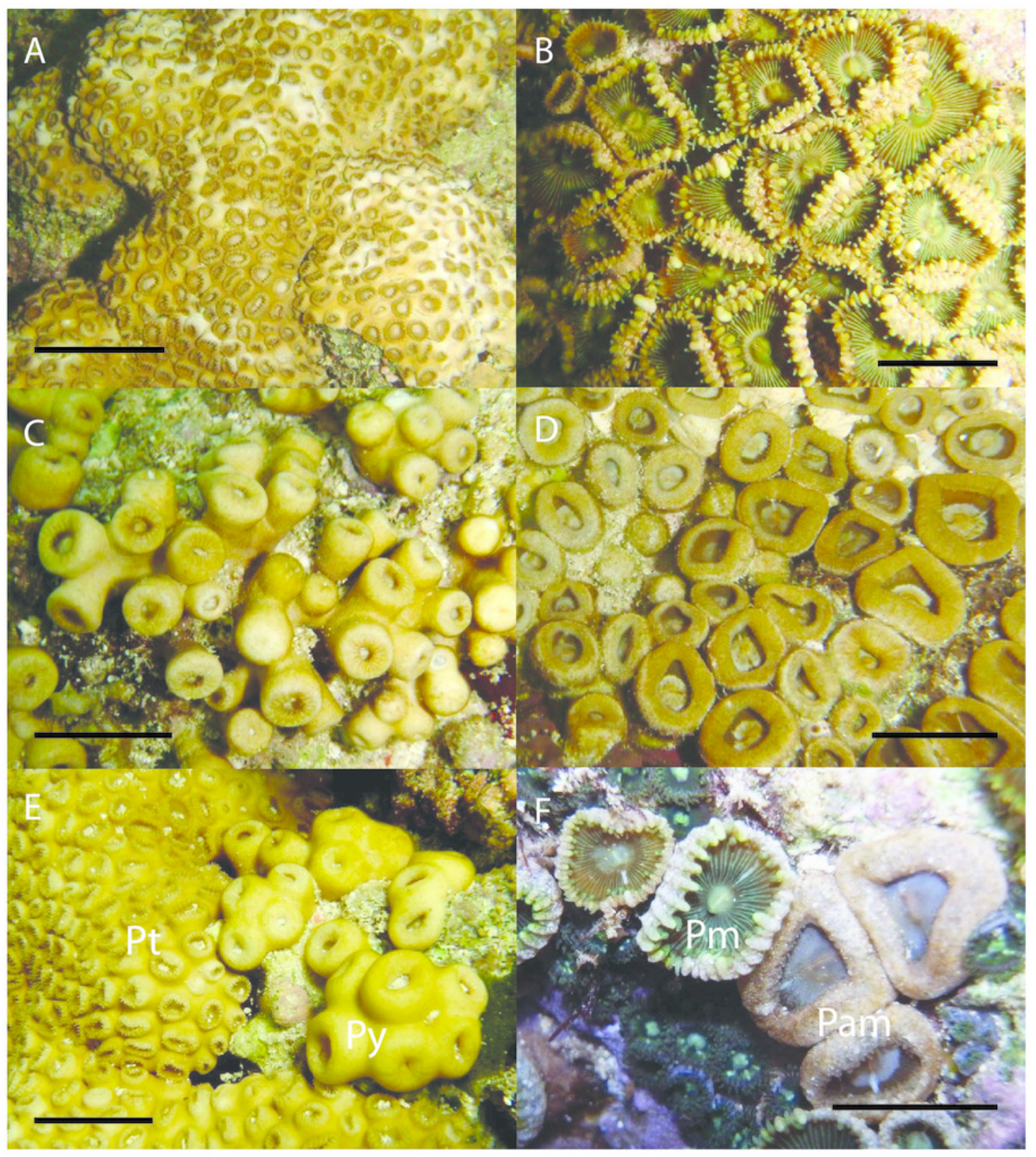


Figure 3

Cnidae of Palythoa species examined in this study.

Cnidae in tentacles, column, pharynx, and filaments of Palythoa aff. mutuki, Palythoa mutuki, Palythoa sp. yoron, and Palythoa tuberculosa. $\mathrm{S}=$ spirocysts, $\mathrm{B}=$ basitrichs, $\mathrm{HS}=$ holotrichs small, $\mathrm{HL}=$ holotrichs large, $\mathrm{P}=$ microbasic $\mathrm{p}$-mastigophores.

A Palythoa aff. mutuki

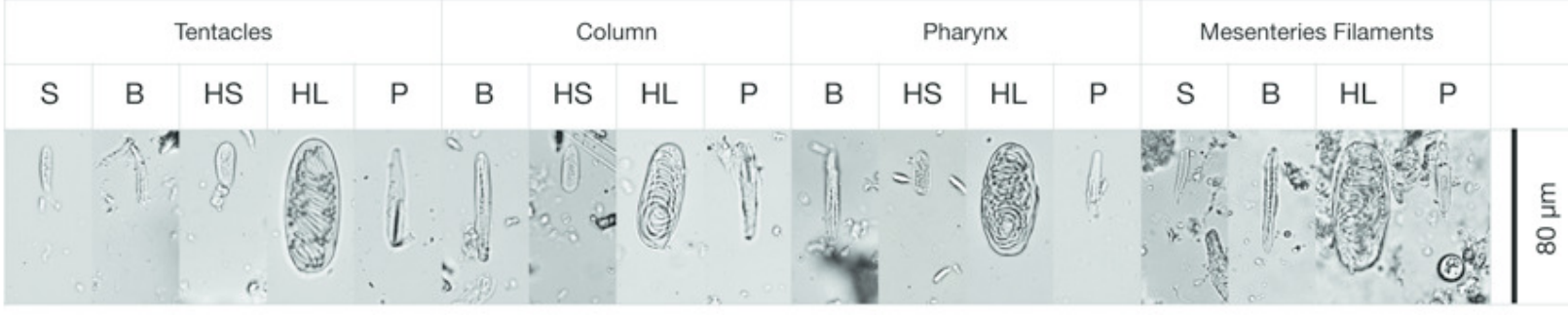

B

Palythoa mutuki

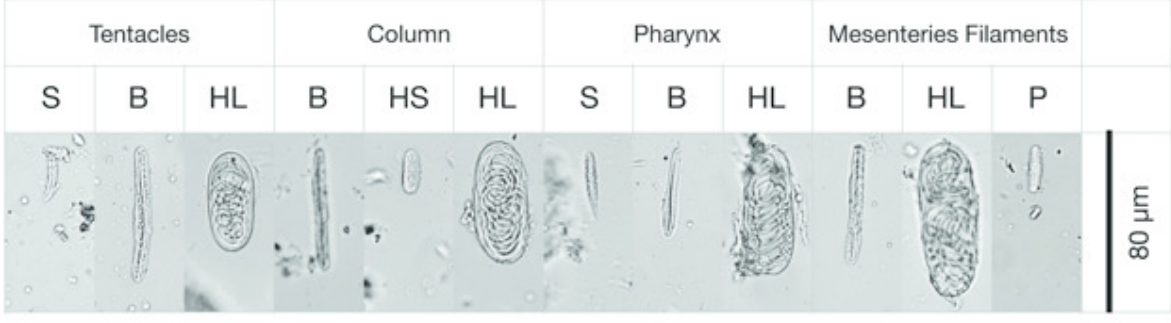

C Palythoa sp. yoron

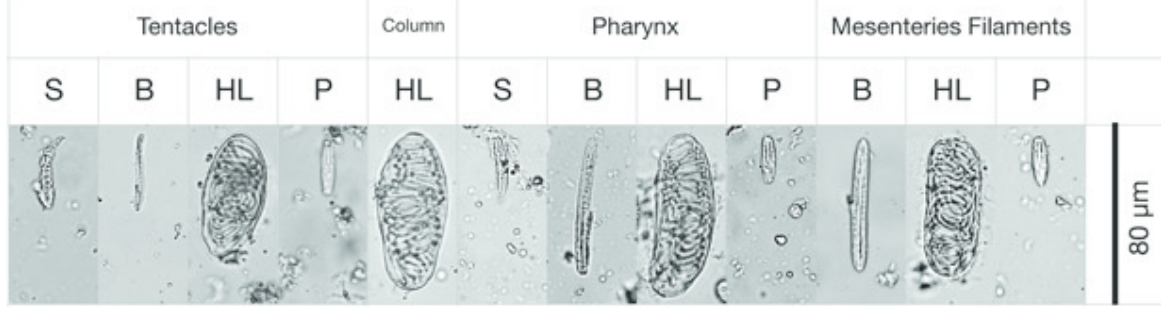

D Palythoa tubercolosa

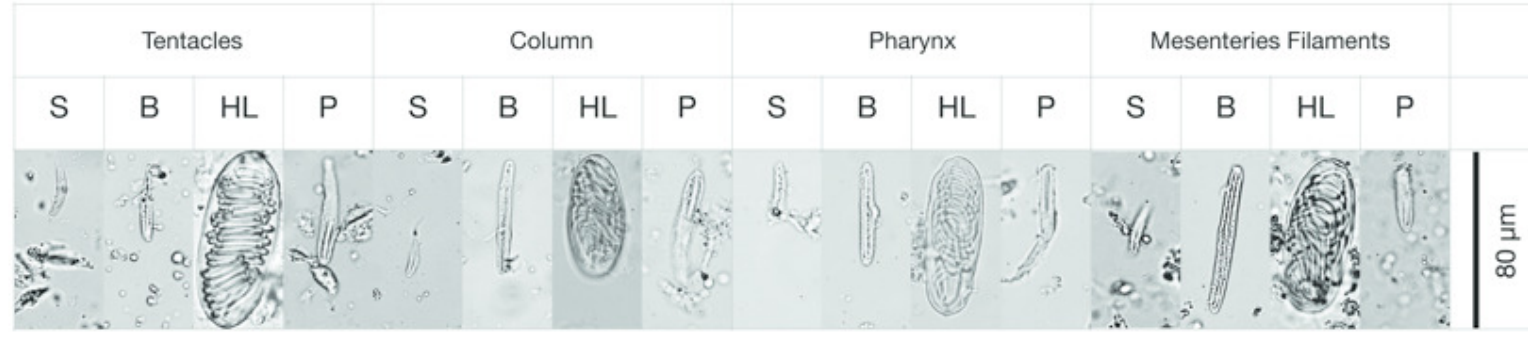




\section{Figure 4 (on next page)}

Monthly change of ratio of number of polyps possessing developing and/or developed ovaries $(\mathrm{N})$ on total number of examined polyps $(\mathrm{Nt})$.

A. Monthly change of ratio of number of polyps possessing developing and/or developed ovaries (N) on total number of examined polyps (Nt) in 2010. Red, $P$. tuberculosa; blue, $P$. mutuki; yellow, $P$. sp. yoron. B. Monthly change of ratio of number of polyps possessing developing and/or developed ovaries (N) on total number of examined polyps (\%) in 2011. Red, $P$. tuberculosa; blue, $P$. mutuki; yellow, $P$. sp. yoron; green, $P$. aff. mutuki. 


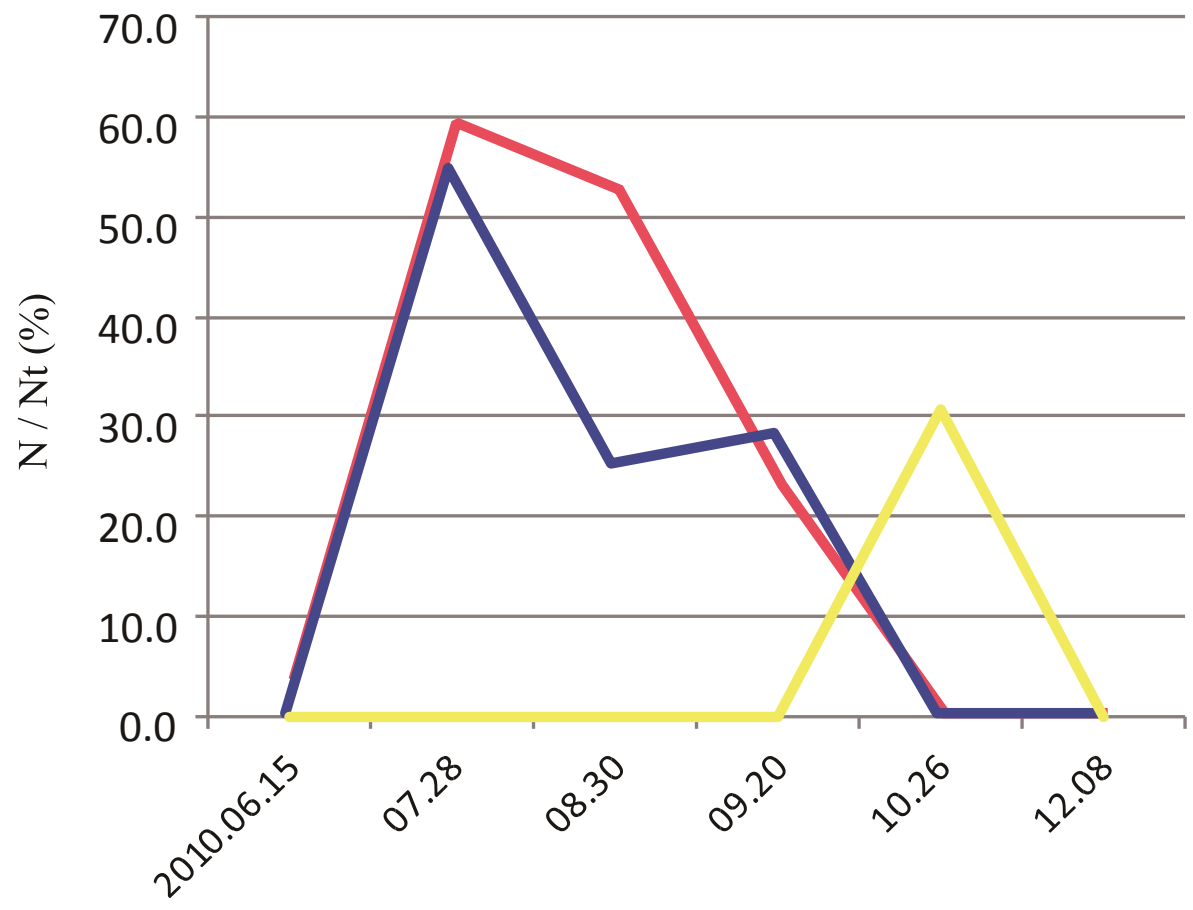

P. tuberculosa

P. mutuki

$P$. sp. yoron

Sampling date

B

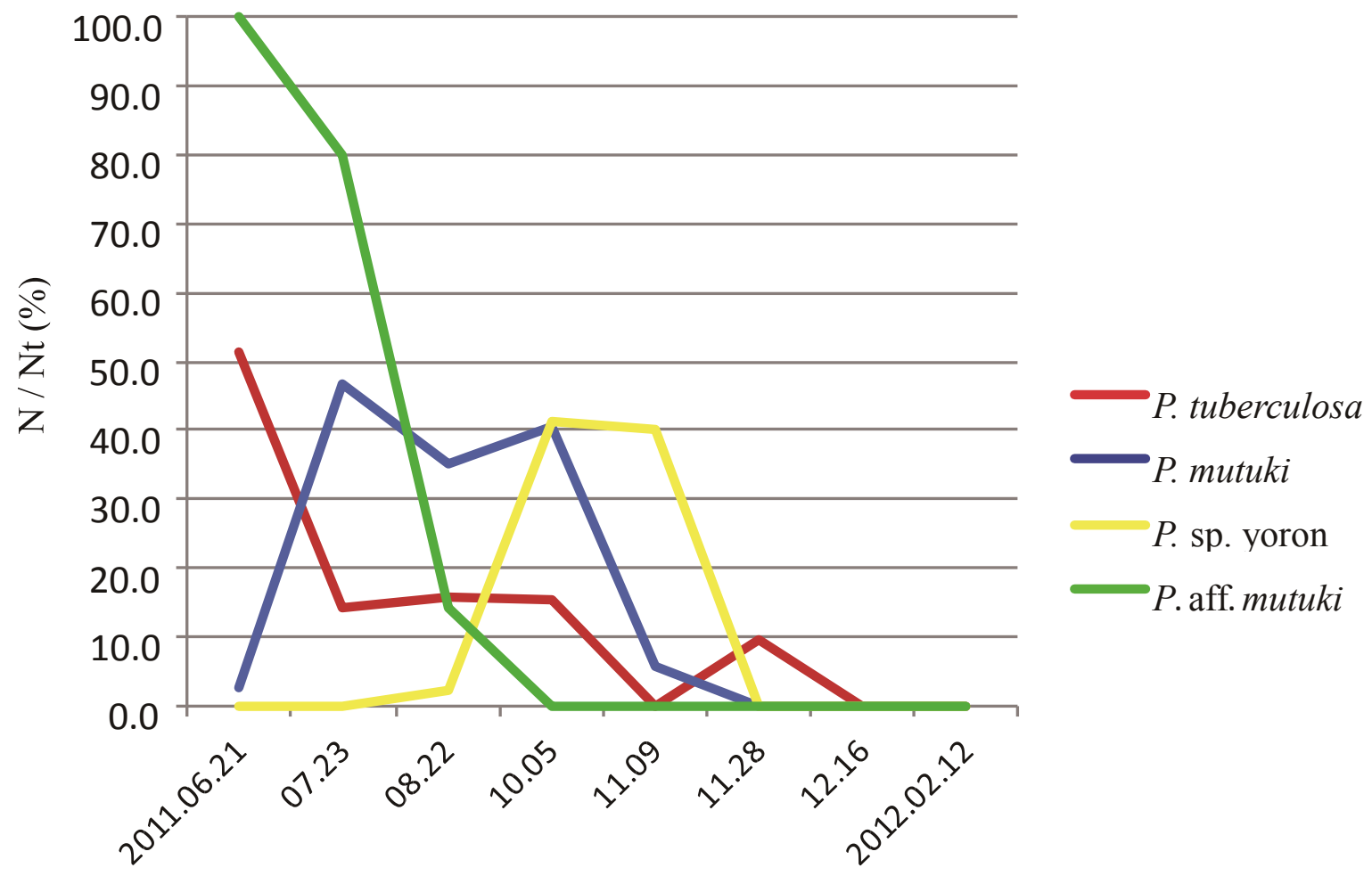

Sampling date 


\section{Figure 5}

Cross sections of Palythoa sp. yoron and $P$. aff. mutuki showing ovary development.

Cross section of polyp of A Palythoa sp. yoron (26 October 2010) and B matured eggs; C $P$.

sp. yoron (9 November 2011) and D germinal ribbon inside a mesentery; E $P$. aff. mutuki (21 June 2011), and $\mathbf{F}$ developed ovaries. Abbreviations: te, tentacles; od, oral disk; co, coenenchyme; mo, mouth; ph, pharynx; eg, eggs; mf, mesenterial filament; gr, germinal ribbon; ov, ovary. Scale bars: $2 \mathrm{~mm}$ in $\mathbf{A}$ and $\mathbf{E} ; 500 \mu \mathrm{m}$ in B; $1 \mathrm{~mm}$ in $\mathbf{C}, \mathbf{D}$ and $\mathbf{F}$. All images taken by M. Mizuyama. 


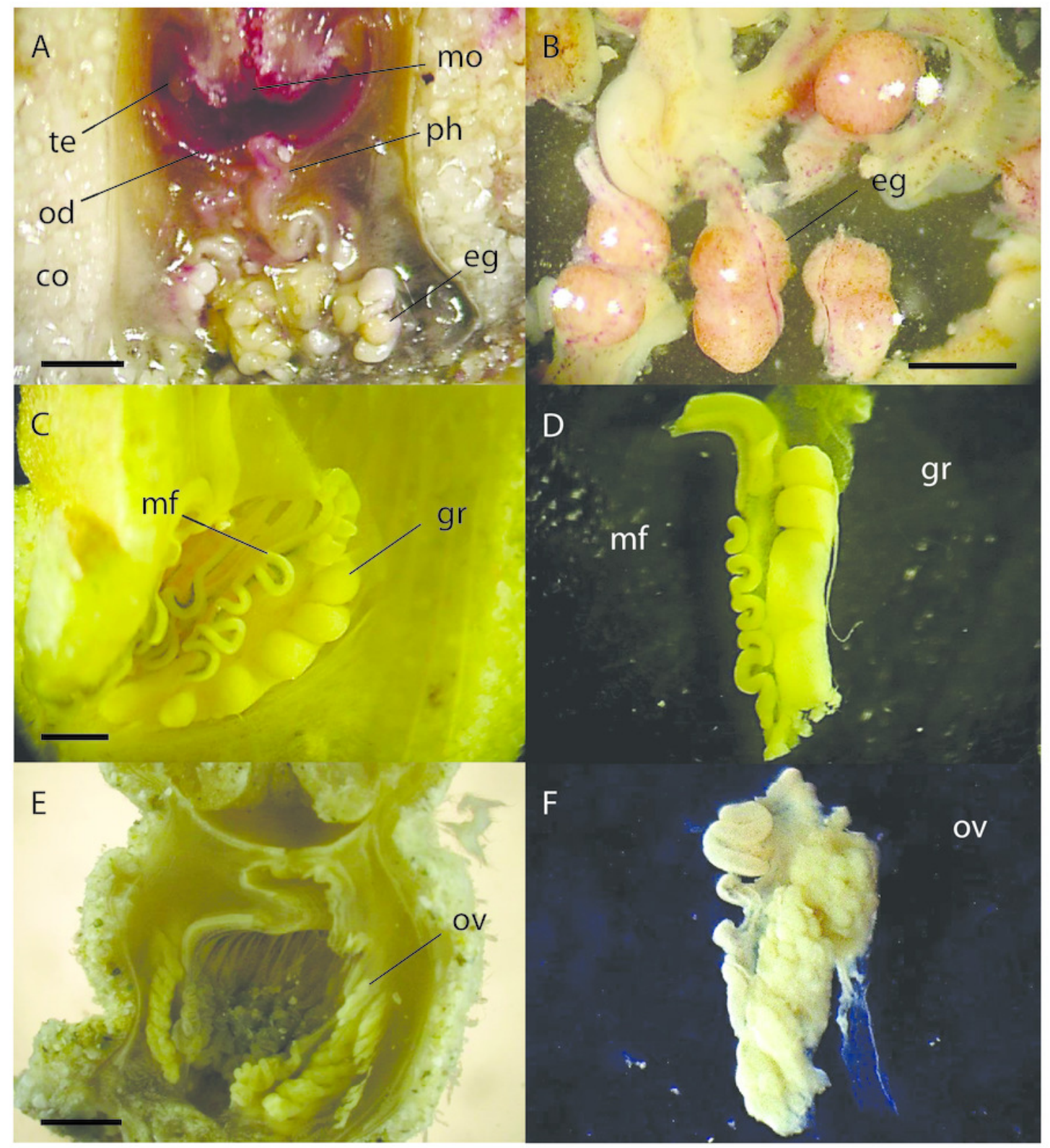




\section{Figure 6}

Phylogenetic trees of four DNA markers for Palythoa species examined in this study.

A. Maximum likelihood (ML) tree of cytochrome oxidase subunit I (COI) sequences. B. ML tree of mitochondrial 16S ribosomal DNA (mt16S rDNA) sequences. C. Maximum likelihood tree of internal transcribed spacer of ribosomal DNA (ITS-rDNA) sequences. D. Maximum likelihood tree of asparagine-linked glycosylation 11 protein (ALG11) region. Values at branches represent ML and NJ bootstrap probabilities, respectively ( $>50 \%)$. Bayesian posterior probabilities of $>0.95$ are represented by thick branches.

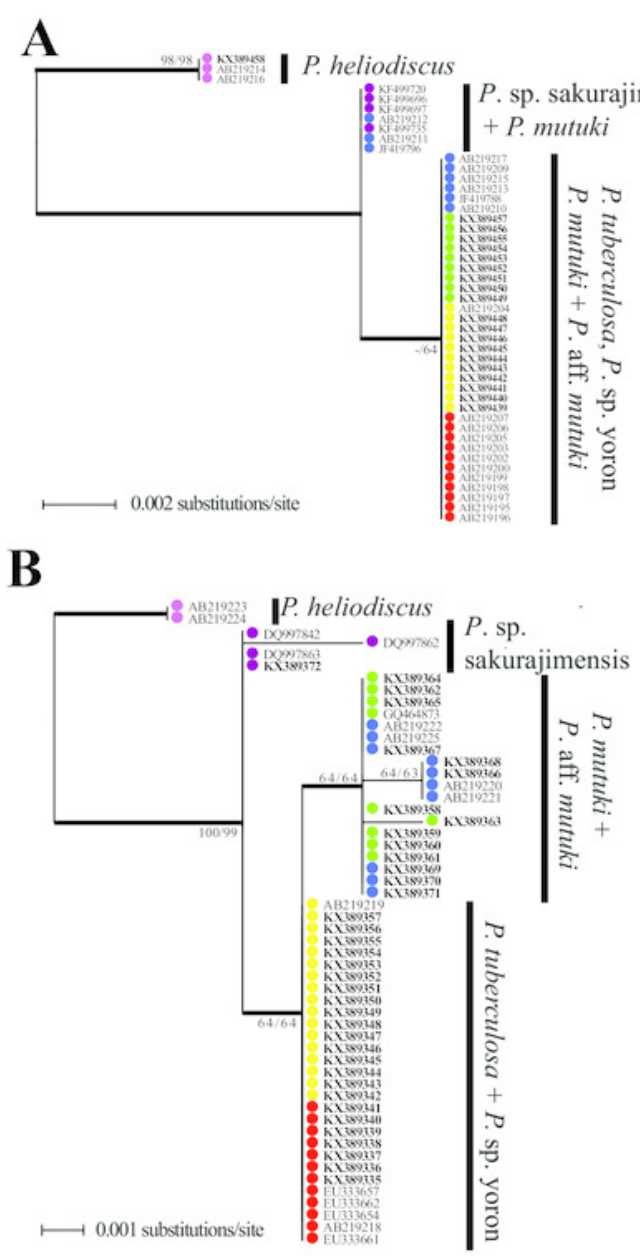

D
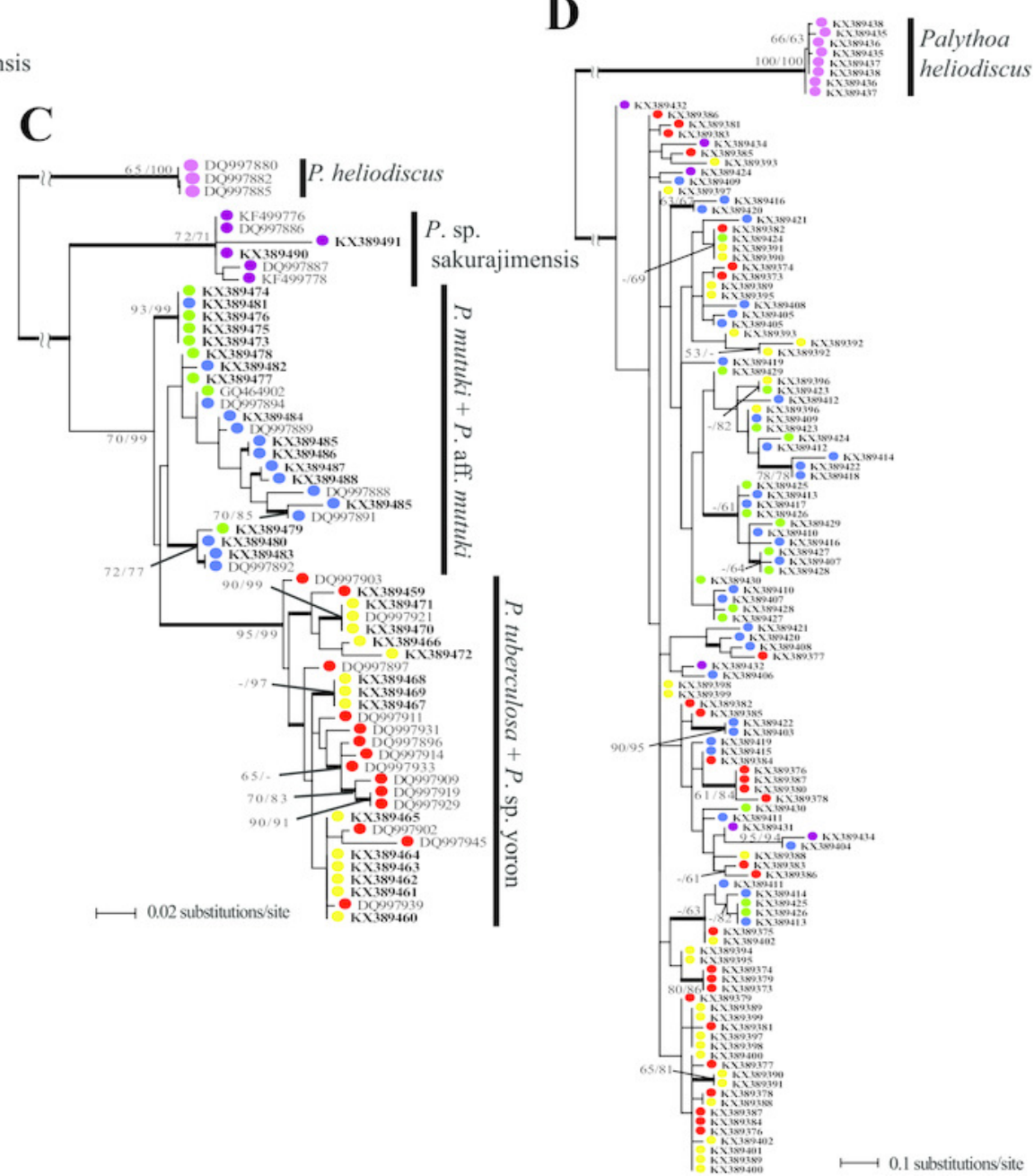
Figure 7 (on next page)

Species trees for Palythoa under A six species model, and B four species model. Values at branches represent posterior probability. 
$A_{\text {PeerJ }}$

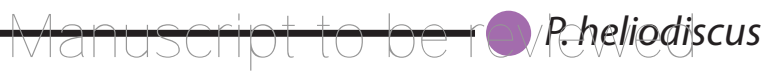
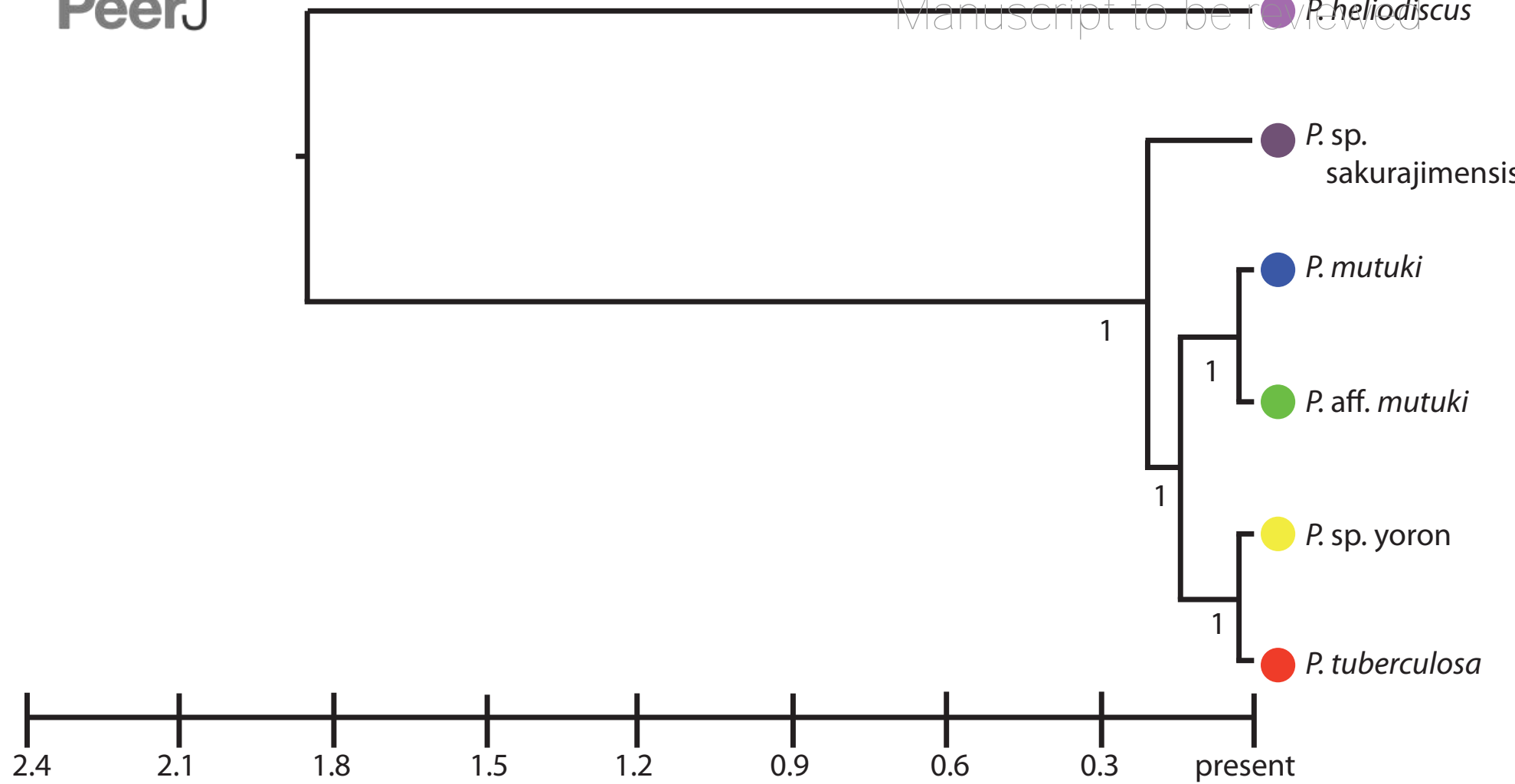

time (mya)

B
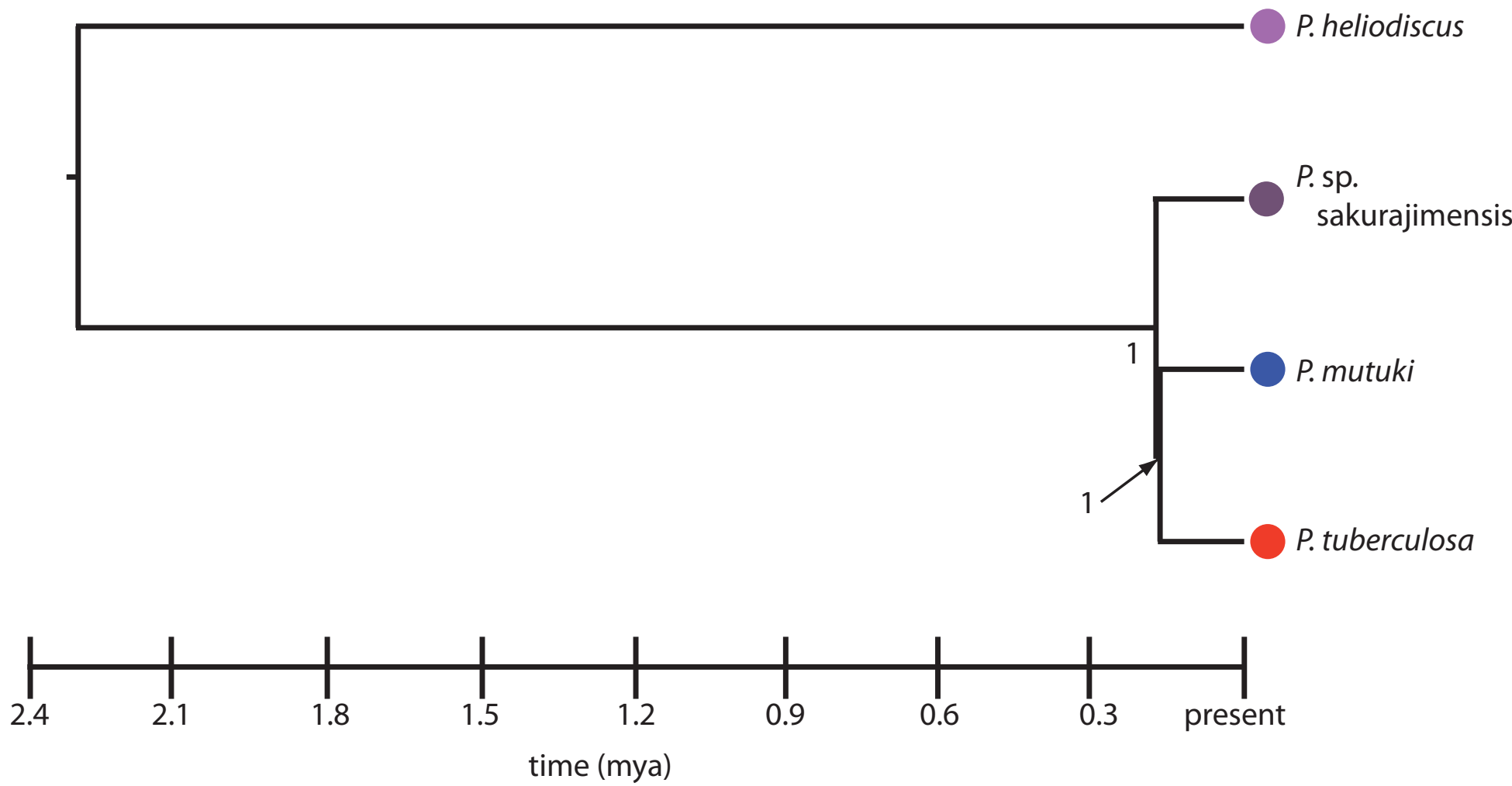